\title{
Genetics of Castes and Tribes of India: Glucose-6-Phosphate Dehydrogenase Deficiency and Abnormal Haemoglobins (HbS and HbE)
}

\author{
M.K. Bhasin \\ Department of Anthropology, University of Delhi, Delhi 110 007, India
}

KEYWORDS Population genetics; breeding population; glucose-6-phosphate dehydrogenase deficiency; haemoglobin
variants; climatic factors

ABSTRACT The discipline of Biological Anthropology (or Human Biology) incorporates study of biology and environmental factors, as well as the forces of micro-evolution leading to macro-evolution, which ultimately influences the structure of human populations. In the present paper and attempt has been made to study the distribution of Glucose-6-Phosphate Dehydrogenase Deficiency and Abnormal Haemoglobins (HBS and HBE) frequencies among the people of India, which are analysed in relation to ecological, socio-economic and linguistic factors.

\section{INTRODUCTION}

Biological Anthropology deals with the comparative biogenetics of man. Within the various fields of research of the present Biological Anthropology the study of human evolution as well as the study of genetic variation in modern man hold an eminent place. An important branch of Biological Anthropology is therefore Population Genetics, which deals on the one hand with exact genetic descriptions of human population, but which on the other hand tries to find out the reasons for genetic differences among them. To study these genetic differentiation processes in man, which are obviously still ongoing, reliable population data are necessary. As far as the various genetic markers of the human blood are concerned such comprehensive reviews have been given $e . g$. by Mourant et al. (1976), Steinberg and Cook (1981), Tills et al. (1983), Roychoudhury and Nei (1988) and Walter (1988). The existence of genetic variation in man is caused by many factors, among which selection, migration and gene flow, genetic drift and founder effects are the most important ones. By means of many examples, Vogel and Motulsky (1997) have shown the importance of these factors for the understanding of genetic variation in man. Mourant et al. (1978) have reviewed the associations between genetic markers of the blood and diseases, which are of considerable interest in this connection.

Postal address: Dr. M.K. Bhasin, B-2 (GF), South City II, Gurgaon 122 002, Haryana, India
The unit of study is genetic variation in man is a "breeding population", also referred to as a "Mendelian population". Following Harrison (1988) one can point out that "the collective unit of evolution is the population and it is in populations that all the forces we have considered operate" (p. 326). Thus selection, gene flow, genetic drift, founder effects etc. are acting on and in populations and shape their specific genetic profiles in the course of time. The "breeding population" is the minimal integrated unit of evolutionary changes. As far as delineating evolutionary factors are concerned, the "breeding populations" as a unit of study meet almost every logical requirement unit and any change in its genetic profile from one generation to the next will constitute an evolutionary change.

The impact of the population approach on the study of genetic variation in man has been to focus attention on "breeding populations" as biological or evolutionary units in man and to describe them in terms of gene frequencies or if this is not possible (anthropometric, morphological, dermatoglyphic, etc. traits) in terms of phenotype frequencies and mean values, respectively. Such exact and comprehensive descriptions are the basic requirements for the understanding of genetic variation in man and thus for the analysis of the various evolutionary factors, which caused this variation in the course of time.

The populations of India and other South Asian countries offer great opportunities to study 
genetic variability. Perhaps, nowhere in the world people in a small geographic area are distributed as such a large number of ethnic, caste, religious and linguistic groups as in India and other South Asian countries. All these groups are not entirely independent, people belong concurrently to two or more of these groups. People of different groups living side by side for hundreds or even thousands of year try to retain their separate entities by practising endogamy.

The aim of the study is to have a satisfactory knowledge of micro-evolutionary processes as they are reflected in genetic and morphological traits in human populations. This variability has been studied in terms of natural regions, climatic factors, climatic regions, political division of India, ethnic groups, traditional occupations and linguistic groups (For details see Bhasin 1988; Bhasin et al. 1992, 1994; Bhasin and Walter 2001). In this paper an attempt has been made to report the Glucose-6-Phosphate Dehydrogenase Deficiency and haemoglobin variants among the people of India and factors responsible to operate in favour of these traits.

\section{IDENTIFY AND DISTINGUISH THE PEOPLE}

For the biogenetical study of the people of India, researchers have generally used the following criteria to identify and distinguish the people: 1. Regional Groups, 2. Ethnic Groups, 3. Linguistic Groups, and 4. Religious Groups.

It should, however, be kept in mind that these are the convenient units of study, although there are significant levels of overlapping between them. For example, an occupational group pursuing traditional job inhabits a region, shares religion with other categories, belongs to one or the other language group and has an aggregation of ethnic properties. But in the human population genetic studies, out of these criteria one is chosen (Bhasin 1988).

In the present study an attempt has been made to analyse the above mentioned biogenetical traits into 1. Regional Groups, 2. Ethnic Groups, 3. Traditional Occupational Groups and 4. Linguistic Groups.

\section{REGIONAL GROUPS}

These can be divided into the following groups:
1. Natural Regions of India

2. Climatological Factors and Climatic Regions of India

3. Political Division of India

Each region has its own characteristics and a brief description of each one will give an idea of what it constitutes of.

\section{Natural Regions of India}

The natural regions have broad uniformity in their characteristics, such as relief, geomorphological history, drainage, climate, soil, natural vegetation and wild life. Broadly speaking the Indian sub-continent may be divided in the following natural regions:

1. The Himalayan Mountain Complex

2. The Indus-Ganga-Brahmaputra Plain

3. The Peninsular Plateau and

4. The Islands

\section{Climatological Factors and Climatic Regions of India}

Various climatological factors (Rainfall, Humidity, Temperature) and Altitude have been considered to study correlations with different biological traits. The values for the climatological factors are after "Climatological Tables of Observations in 1931-1960" Meteorological Department, Government of India, New Delhi.

A climatic region generally possesses a broad uniformity in climatic conditions produced by combined effects of climatic factors. India can be divided into the following climatic regions after Köppen's method, based on the monthly values of temperature and precipitation:

(1) Tropical Savannah Type, (2) Monsoon Type with Short Dry Season, (3) Monsoon Type with Dry Season in High Sun Period, (4) Semiarid and Steppe Climate, (5) Hot Desert Type, (6) Monsoon Type with Dry Winters, (7) Cold Humid Winters Type with Shorter Summer, and (8) Polar Type.

\section{Political Division of India}

India is a Union of States. Comprising 25 States ${ }^{1}$ and 7 Union Territories, according to the Census 1991, there are 4689 towns and 587,226 inhabited and 47,095 uninhabited villages in the country. The country had 466 districts in 1991.

India Political and Ethnic Zones: The weighted mean values of various biological traits 
have been classified into 25 States and 7 Union Territories (U.T.) which have been categorised as follows (after Bhasin, 1988):

I. North India, II. West India, III. East India, IV. Central India, V. South India, and VI. Islands. Himalayan Region may be divided into three divisions, i.e., A) Western Himalaya, B) Central Himalaya, and C) Eastern Himalaya as follows:

I. North India:

(A) Western Himalaya (S. No. 1, 2):

(1) Jammu and Kashmir, (2) Himachal Pradesh, (3) Punjab, (4) Chandigarh (U.T.), (5) Haryana, (6) Delhi (U.T.), (7) Uttar Pradesh

(B) Central Himalaya (S.No.7, Eight Districts of Uttar Pradesh)

[(i) Almora, (ii) Chamoli, (iii) Dehra Dun, (iv) Garhwal (Pauri), (v) Naini Tal, (vi) Pithoragarh, (vii) Tehri Garhwal, and (viii) Uttarkashi.] and 8. Rajasthan

II. West India:

(1) Gujarat, (2) Maharashtra, (3) Goa², (4) Daman and Diu ${ }^{2}$ (U.T.) and (5) Dadra and Nagar Haveli (U.T.)

III. East India:

C) Eastern Himalaya: (S. No.1 to 8 and Darjeeling District of West Bengal)

(1) Arunachal Pradesh, (2) Assam, (3) Nagaland, (4) Manipur, (5) Mizoram, (6) Tripura, (7) Meghalaya, (8) Sikkim, (9) West Bengal, (10) Bihar, and (11) Orissa IV. Central India:

(1) Madhya Pradesh

V. South India:

(1) Karnataka, (2) Andhra Pradesh, (3) Tamil Nadu, (4) Kerala and (5) Pondicherry (U.T.).

VI. Islands:

(1) Lakshadweep (U.T.) and (2) Andaman and Nicobar Islands (U.T.).

\section{ETHNIC GROUPS}

An aggregation of biological and sociocultural characteristics constitutes an ethnic group. Within the category of Ethnic Group, we include Castes, Scheduled Castes, Scheduled Tribes and Communities (the names of Scheduled Castes and Scheduled Tribes after Manual of Election Law 1982, Government of India, New Delhi). Biological anthropological studies of such ethnic groups as well as "Communities" have been reported in India. By Community we generally refer to a group of people who may have occupational, linguistic, religious or regional characteristics (Bhasin 1988).

\section{TRADITIONALOCCUPATIONALGROUPS}

In the traditional society, there were occupational guilds. The Chaturvarna system with its division into Brahman (priestly caste), Kshatriya (warrior caste), Vaishya (land owners and traders) and Sudra (labouring caste) was based on occupational differentiation. The occupations are grade manual labour is looked down upon, and those dealing with swineherding, scavenging, butchery, removal of night soil are regarded as polluting (Bhasin 1988). The caste based division of occupation is 1 . Priesthood, 2. Warfare, 3. Trade and Commerce, 4. Agriculture, 5. Animal Husbandry, 6. Artisan, and 7. Menial Workers.

\section{LINGUISTIC GROUPS}

Although the Schedule VIII recognizes fifteen languages in India, there are innumerable dialects which change after few scores of kilometers. Linguistic diversity is an important factor in the formation of regional groups, and it also reflects the regional differentiation. The four- fold regional division can be seen for the major languages, i.e., (i) the Dravidian region of the south; (ii) the Indo-Aryan regions of the north and north-west; (iii) the Mon Khmer and the Tibeto-Burman region of the north-east and the Himalayan region; and (iv) the Austric region of the Aravalli-Vindhya-Chota Nagpur complex. These languages are again divided into subfamilies and groups as follows:

\section{Language Classification-Indian Languages}

The family, branch, group and language of India are as follows:

I. AUSTRO-ASIATIC FAMILY

Mon-Khmer Group (Mon-Khmer Branch)

Munda Group (Munda Branch)

II. TIBETO-CHINESE FAMILY

SIAMESE-CHINESE SUB-FAMILY

Tai Group

TIBETO-BURMAN SUB-FAMILY

Tibeto-Himalayan Branch

Bhotia Group (Tibetan Group)

Himalayan Group (Pronominalized/Non- 
Pronominalized Himalayan Group)

North-East Frontier Group (North Assam Branch)

Assam-Burmese Branch

Bodo Group (Bara or Bodo Group)

Naga Group

Kachin Group

Kuki-Chin Group

Burma Group

III. DRAVIDIAN FAMILY

South Dravidian Group

Central Dravidian Group

North Dravidian Group

IV. INDO-EUROPEAN FAMILY ARYAN SUB-

FAMILY

Dradic (or Pisacha) Branch

Kafir Group

Khowar Group

Dard Group

Indo-Aryan Branch:

Outer Sub-Branch

North-Western Group

Southern Group

Eastern Group

Bihari Group (Bhojpuri, Maithili \& Magahi

Sub-Group)

Mediate Sub-Branch/Inner Sub-Branch:

Mediate Group/Central Group/Pahari Group

Mediate Group/Central Group

Pahari Group

Eastern Pahari

Central Pahari

Western Pahari

\section{MEAN WEIGHTED VALUES}

To discern the pattern of regional groups, ethnic groups, traditional occupational groups and linguistic groups using the frequency data, the mean weighted values of the biological traits have been calculated and estimates for the various groups are presented.

\section{GLUCOSE-6-PHOSPHATE DEHYDROGENASE (G-6-PD) SYSTEM} (E.C.1.1.1.49)

Glucose-6-phosphate dehydrogenase (G-6$\mathrm{PD})$ enzyme is necessary as a catalyst in a biological oxidation-reduction reaction of glucose-6-phosphate-one of the stages in the metabolism of carbohydrates. The G-6-PD deficiency disease was discovered when a number of Americans of African and Asian descent were treated with certain antimalarial drugs particularly primaquine, which produced a mild haemolysis in these individuals (Carson et al. 1956). Investigations showed them to be deficient in the red cell enzyme G-6-PD. A number of other drugs chemically related to primaquine produce haemolysis when given to individuals deficient in G-6-PD (WHO 1967). Favism, a haemolytic condition produced by eating fava beans (Vicia fava) is observed among populations living in the Mediterranean area and is believed to be connected with G-6-PD deficiency. The G-6-PD deficiency in red cells is inherited as an X-linked trait (chromosome location Xq28). Heterozygous females are usually intermediate between normal individuals and those clearly G-6-PD deficient.

Two common types referred to as A and B could be demon strated by electrophoresis. The commonest allele in all populations is $G 6 P D * B$. In Africans two other alleles $G 6 P D * A+$ and $G 6 P D^{*} A$ - are also relatively common each with allele frequencies between 0.01 and 0.25 in different populations. In Mediterranean countries and the Middle East another allele $G 6 P D *$ Mediterranean is relatively common. Certain electrophoretic variants also occur in Southeast Asia (G6PD*Canton) and in Greece (G6PD*Athens).

Investigations of enzyme in different human populations have shown many variants-more than 300 different variants have been described on the basis of their biochemical properties (Luzzatto and Mehta 1989; Beutler 1990) and most of them are relatively rare, but some have appreciable frequencies in certain localised populations. So far seven different G-6-PD variants namely-G6PD* Andhra Pradesh (Rattazzi 1966), G6PD*Cutch (Goshar 1979), G6PD* Jammu (Beutler 1975), G6PD* Kalayan (Ishwad and Naik 1984), G6PD*Kerala (Azevedo et al. 1968), G6PD*Porbandar (Cayani et al. 1977; Goshar 1979) and G6PD*West Bengal (Azevedo et al. 1968) have been reported from India. With the cloning and sequencing of G-6PD the variants that were thought to be different have proven to be identical, and those that were thought to be the same are now seen to be heterogenous (Martini et al. 1986; Persico et al. 1986a, b; Takizawa et al. 1986 and Yoshida and Takizawa 1986).

Most of the studies on G-6-PD published prior 
to the WHO Report (1967) were based on investigations carried out on patients in hospitals, manifesting clinical conditions such as haemoglobinuria, neonatal jaundice, druginduced haemolytic anaemia etc. It has been estimated that approximately hundred million people suffer from G-6-PD deficiency in different parts of world (Azevedo et al. 1968; WHO 1967).

The Rhesus and ABO blood groups have been analysed in G-6-PD deficient and nondeficient samples. The frequency of Rhesus negatives was observed low among Sardinians and Congolese Bantus, both of whom show very high frequency of primaquine sensitivity (Sonnet and Michaux 1960). In the distribution of B and O groups, Tarlov et al. (1962) observed relative rarity of B group in deficients. However, Baxi et al. (1963) and Jolly et al. (1972) failed to observe such differences.

Prenatal selection and foetal development disturbances are reported in carriers of G-6-PD deficiency by Toncheva and Tzoneva (1985) and they observed that the incidence of spontaneous abortions in first trimester is higher (21.7 per cent) in the women of heterozygous carriers of G-6-PD deficiency as compared to control group ( 9.3 per cent).

Limited information on the distribution of G6-PD phenotypes is available among the population groups reported from different areas. It is believed that red cell G-6-PD deficiency is one of the important markers to explore the ecoand pharmacogenetic aspects of a population, due to its association with past malarial incidence.

G-6-PD deficiency was mainly found in populations originating from tropical and subtropical areas of the world. The geographic distribution was similar to that of falciparum malaria and suggested that G-6-PD deficiency similar to the sickling trait owed its distribution to selection by this malarial organism. Evidence related to a correlation of the frequencies of the sickling gene and that of A-type of G-6-PD deficiency exists in African countries and that between $\beta$-Thalassemia and the Mediterranean type of G-6-PD deficiency in Sardinia.

The deficiency of G-6-PD is found in a belt extending from Mediterranean area through Southwest Asia and India to South east Asia. The G6PD*def is very much prevalent in Saudi Arabia (varies from 0.07 to 0.44 ). Perhaps the highest frequency of deficiency recorded is among Shia of Al Qatif, Saudi Arabia (0.44), whereas the incidence in other Southwest Asian countries ranges from 0 to 0.21 . From East Asian populations the frequency of $G 6 P D *$ def is low (0.01 to 0.05$)$. Among Khmer population from Vietnam (South east Asia) the frequency of $G 6 P D *$ def is highest (0.15 to 0.35) and in Central and North-East Thailand the incidence is 0.11 to 0.17 , but in most populations of Southeast Asian region the frequencies are less than 0.10 . In the Indian region, it is around 0.19 (Mourant et al. 1976).

According to WHO Report (1966), the frequency of $G 6 P D *$ def in India ranges between 0.04 and 0.19 . Since most of the studies published prior to this report were based on investigations carried out on patients in hospitals, studies on well defined populations are too few to allow a fair estimate of regional variations in the enzyme deficiency.

From a total of 224 studies reported among Indian populations the frequency of $G 6 P D * d e f$ is 0.045 (varies from complete absence to 0.271 among Angami Nagas studied by Seth and Seth 1971). The frequency is higher in East India zone (0.067 from 24 studies) as compared to other zones (Central India from 3 studies - 0.061; North Indian from 34 studies - 0.058; West India from 110 studies - 0.032 and South India from 53 studies 0.032 ). From Himalayan region the frequency of $G 6 P D^{*}$ def is high (0.087) as compared to nonHimalayan region (0.043) from where only 15 studies are reported. Among scheduled tribes the frequency is highest $(0.055)$ from 53 studies as compared to other ethnic groups (community from 93 studies - 0.049; caste from 49 studies 0.036 and scheduled caste from 29 studies - 0.027). It has been observed that the number of studies available from different zones, regions and ethnic groups are not well distributed, therefore it is not possible to evaluate the distribution of this trait precisely (Table 1).

The frequency of $G 6 P D *$ def is quite high from the Himalayan mountain complex [ $(0.095$, varies from 0.030 to 0.271 among Nagas of Nagaland, in whom highest frequency is reported, albeit, recently Saha et al. (1990a) observed near absence of the allele among Nagas)] as compared to other natural regions. The frequency of deficients is 0.060 and 0.042 from monsoon type with dry winters and tropical savannah type climatic regions, respectively from where maximum number of studies have been conducted (Bhasin et al. 1994; Bhasin and Walter 2001). 


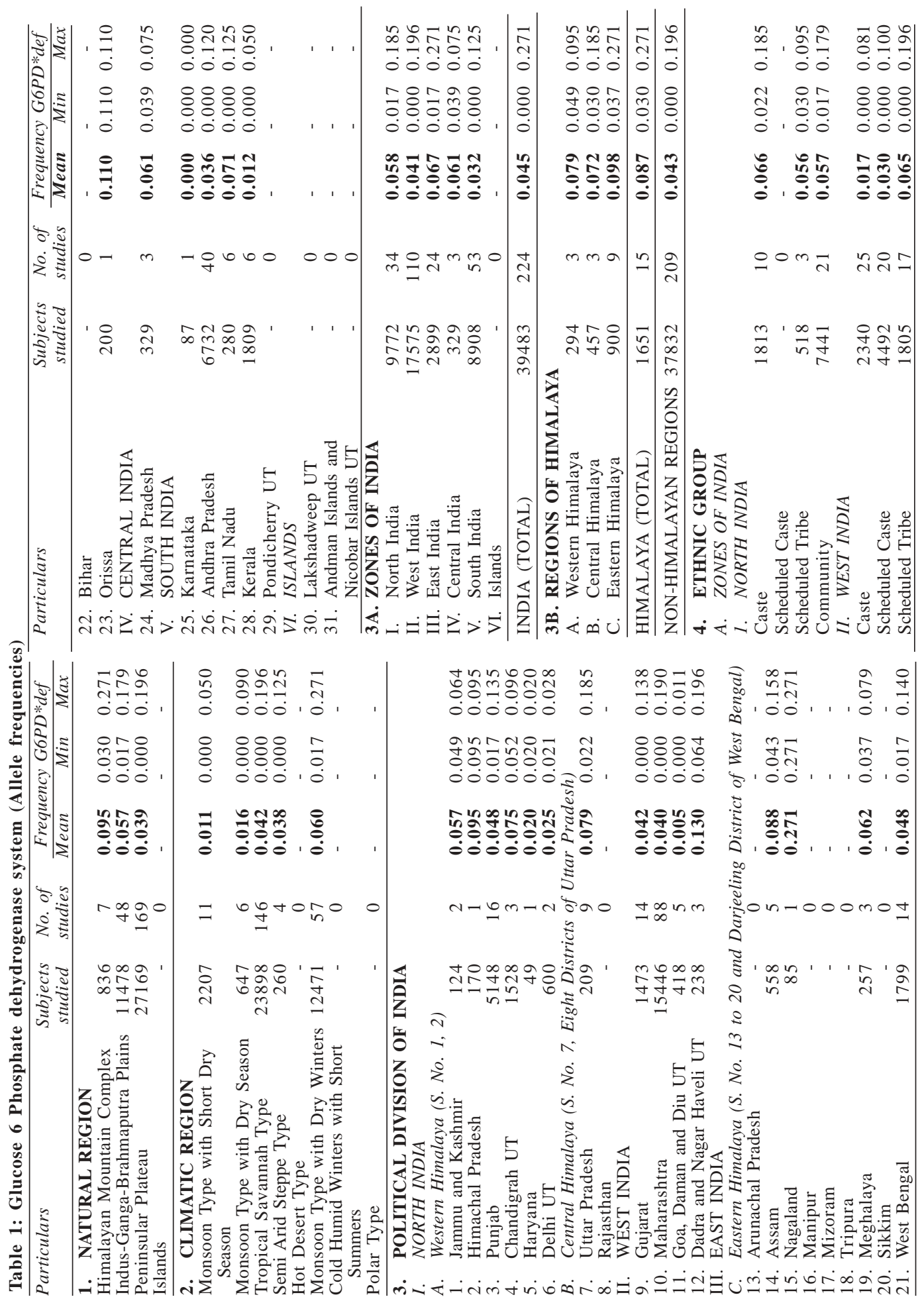




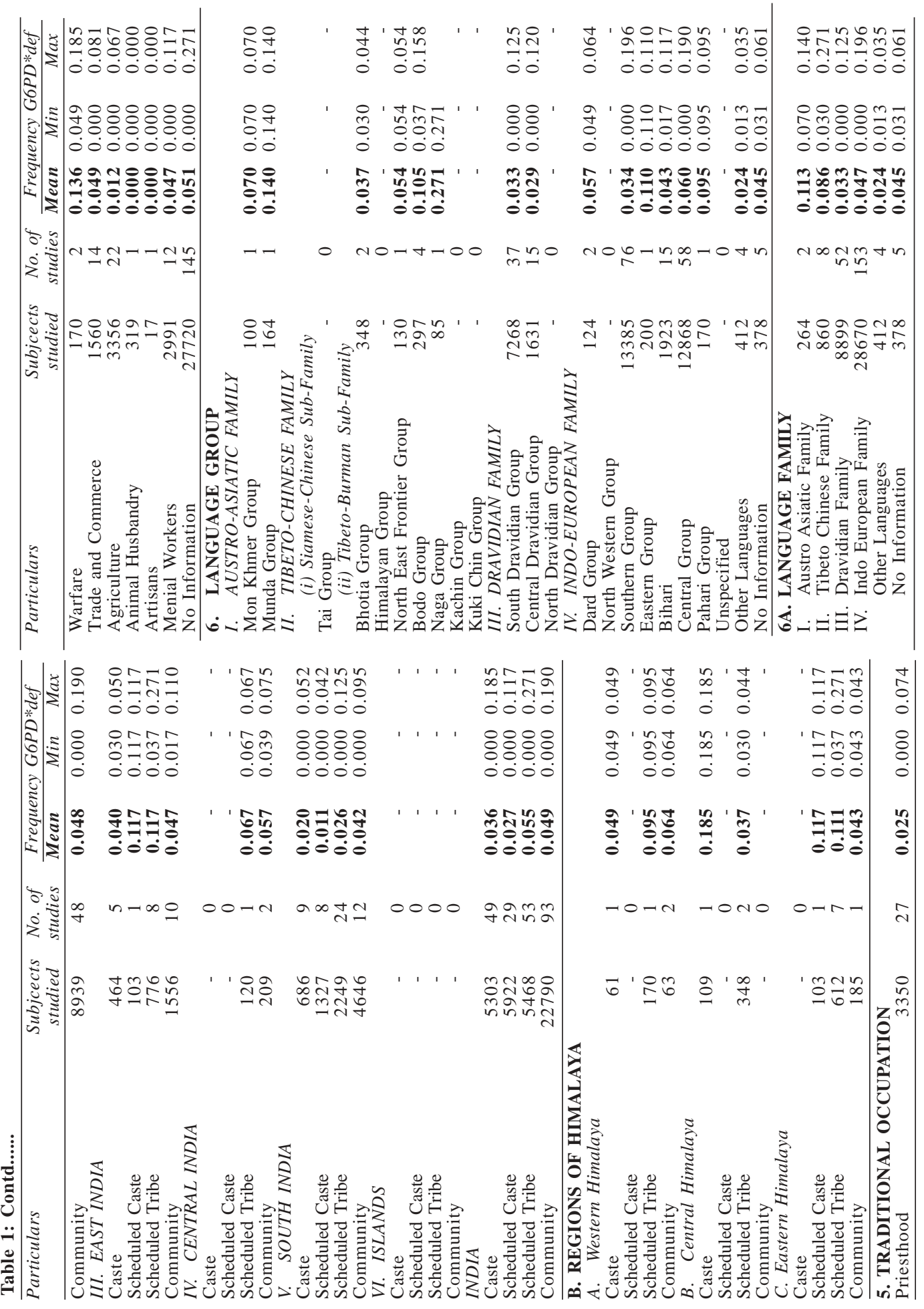


The frequencies of $G 6 P D *$ def allele in different zones and regions of India present a heterogeneous picture. From North India, the frequency of $G 6 P D^{*}$ def is comparatively high from all the States and Union Territories as observed from the states of Jammu and Kashmir (0.057 among Pandits and Muslims) and Himachal Pradesh (0.095 among Gaddis) from Western Himalayan region; Punjab (0.048, from where highest frequency is reported among Punjabis), Chandigarh (0.075, among Jat Sikhs - 0.096, Brahmins - 0.074 and Banias - 0.052) and Uttar Pradesh (0.079) and from Central Himalayan region (0.072), whereas from Harayana and Delhi low frequencies are observed (0.020 and 0.025, respectively). Similarly in West India, from the states of Gujarat and Maharashtra the frequencies of $G 6 P D * d e f$ are high $(0.042$ and 0.040 , respectively), Dadra and Nagar Haveli (0.130, Dhodia - 0.063 and Warlis - 0.196 tribal groups), whereas it is almost absent in Goa, Daman and Diu (Saraswat groups). From Bombay (Maharashtra) among Parsis frequency of $G 6 P D *$ def is quite higher than their neighbours, the indigenous Indians. The Parsis came from Persia due to religious persecution after the fall of Zoroastrian Empire in A.D. 651. They settled down around Surat (Gujarat) and later Bombay city became one of their main clusters. Parsis are having a clear-cut genetic profile with a high frequency of ry $\left(R H^{*} c D E\right)$ in the Rhesus complex, G-6-PD deficiency and a previously unknown $G M^{*} 1,3,21$ haplotype at a frequency of 0.03 , very low $K M * 1$, occasional presence of the $\mathrm{HbAS}$ trait and high frequency of $G C^{*} 1 F$ $(0.48)$ and this shows that the Parsis as a result of migration, genetic drift, limited admixture and selection have changed their gene pool during the course of their 1300 years stay in their new location which is quite different from their ancestral one (Undevia 1973; Undevia et al. 1972, 1973; Steinberg et al. 1973; Undevia and Saha 1987). For the high frequency of $G 6 P D^{*} d e f$ explanation is that Parsis, mostly wealthy, had open 'tanks' in the centre of their dwelling compounds and in these mosquitoes were breeding and maintaining a very local endemicity of malaria (Mourant 1983).

From Central India, only one study is available on Bhil tribals among whom the frequency is high (0.067).

From South India, the frequency of $G 6 P D * d e f$ is comparatively low (0.032) as observed from
Karnataka (absent) and Kerala (0.012) except in Andhra Pradesh (0.036) and Tamil Nadu (0.071, high frequency may be due to a small sample of Kurumba tribal among whom quite high frequency is reported 0.125). From East India, the studies available from different areas are either none or a few. From the states of Assam and Meghalaya (Eastern Himalayan region) among the populations with Mongoloid affinities the frequencies are high $(0.088$ and 0.062 , respectively) whereas from the state of West Bengal the frequency is 0.048 (where among all the studies, the allele $G 6 P D^{*}$ def is present and the frequency is highest among Santhal tribals 0.140) and from Orissa in one study among general population the frequency is 0.110 .

In general, the frequencies of $G 6 P D * d e f$ are high in North and West India as compared to South India where the frequencies are uniformally low except in Andhra Pradesh and Tamil Nadu, whereas in East India the studies are not sufficient. However, it is observed that among the populations with Mongoloid affinities from Eastern Himalayan region the frequency is high and among all studies reported from West Bengal, the $G 6 P D^{*}$ def allele is present (Fig. 1).

The allele frequency of $G 6 P D * \operatorname{def}$ correlation with various climatic factors and altitude by different ethnic groups though showing significant differences are not high (Table 4).

Among all the different traditional occupational groups, G6PD*def allele is present and the similar frequencies are found among trade and commerce (0.049) and menial worker (0.047) groups, which indicates gene flow among them as also observed from the study of genetic markers already discussed (Bhasin et al. 1994; Bhasin and Walter 2001).

The frequency of $G 6 P D *$ def is high among speakers of Pahari group (0.095), Dard group (0.057) of Indo-European; North East Frontier group (0.054), Bodo group (0.105) of TibetoChinese; and Mon Khmer group (0.070) of Austro-Asiatic languages from Himalayan region. The frequency is high among the speakers of Central group of Indo-European languages (0.060) whereas among the speakers of Dravidian languages the frequencies are low (0.033 among South Dravidian group and 0.029 in Central Dravidian group). In Munda group, only one study is available, where the frequency is high (0.140).

The origin of G6PD*Mediterranean allele in 


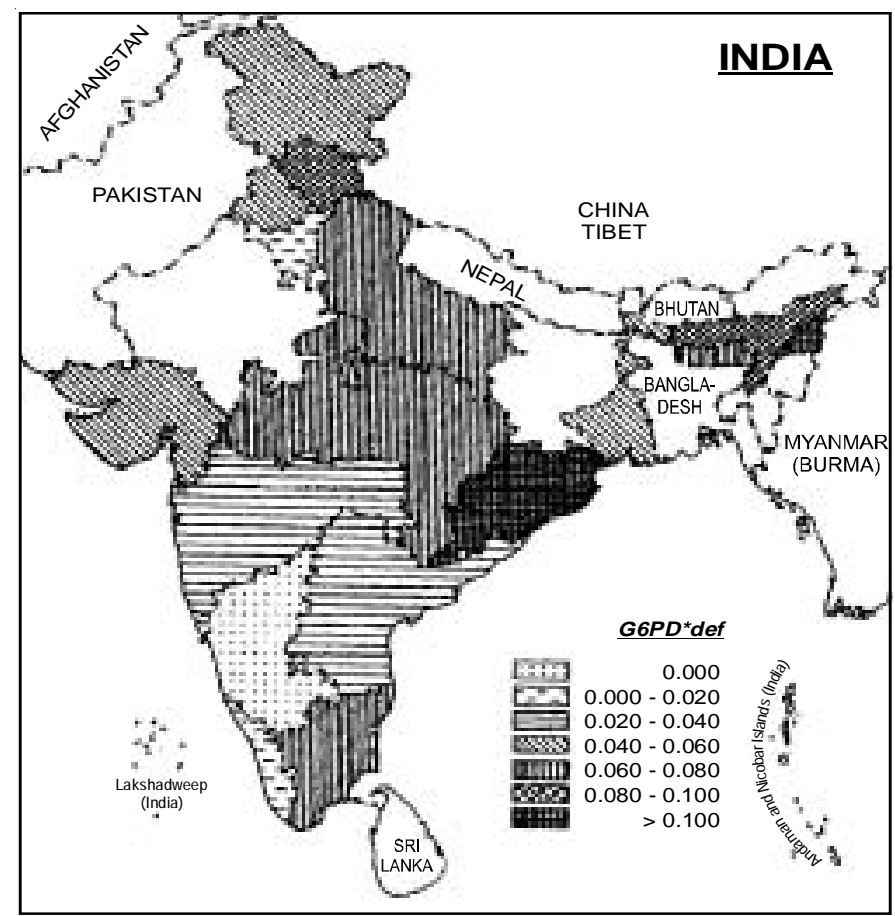

Fig. 1. Allele $G 6 P D^{*}$ def of Glucose-6-Phosphate Dehydronenase System in different regions of India

India and its spread out throughout the region and possibility of malaria exerting pressure for its maintenance in Indian populations pose complicated problems.

About the origin of $G 6 P D *$ Mediterranean allele Baxi (1974) reported that it appears this gene had its passage through the North and then spread throughout the adjoining regions as history records several contacts between the Mediterranean people and Indians. Hence there may be an ancient genetic link between the Greeks, Persians and other non-Semetic Near East inhabitants and the people of Northwest India. As a result, one might expect same similarities in the G-6-PD variants found in this area. It has been observed that in the distribution of $G 6 P D * d e f$ allele among Indian populations, comparatively higher frequencies in the North and West indicate that considerable stability of the $G 6 P D *$ def allele has been attained in these areas. On the other hand, frequencies in South India are uniformaly low except in Andhra Pradesh and Tamil Nadu and in Eastern India, it is difficult to comment as the studies available are few.
With regard to the possibility of malaria exerting selective pressure for the maintenance of the $G 6 P D * d e f$ allele in Indian populations, it has been found that the distribution of G-6-PD is not closely related to that of malaria Table 3 , (Fig. 4). Saha et al. (1990a) observed a very low frequency of G6PD*def among Naga, Hmar, Lepcha and Adi populations in the region of high malarial endemicity and reported this may be due to the fact that these people live at high altitude which probably caused relaxation of selection by malaria. On the other hand, the results of clinical and cellular studies seeking more direct evidence of resistance to malaria among G-6-PD deficient subjects have been somewhat contradictory. Thus it appears that the mechanism of protection afforded by variants of the G-6-PD gene may be complex. Further, the distribution of $G 6 P D * d e f$ allele among Indian populations is difficult to interpret due to very wide range of environmental conditions to which they are exposed, their diversity in ethnic composition (consisting of racial elements of autochthonous, Caucasoid and Mongoloid) and existence of caste and tribal system among them. 
The frequency of $G 6 P D *$ def is 0.045 (varies from complete absence to 0.271 ) among Indian populations and it is high among scheduled tribes $(0.055)$ as compared to other ethnic groups. The frequency is comparatively higher in North and West India zones, which indicates considerable stability of this allele in these areas, whereas in South India it is uniformly low except in Andhra Pradesh and Tamil Nadu and from East India the studies are too few to evaluate. Among the speakers of different languages, the frequencies are high in Mon Khmer group, North East Frontier group, Bodo group and Pahari group from Himalayan region and low among the speakers of Dravidian languages. The studies available from different ecological settings are not sufficient as yet to evaluate the distribution of this genetic marker in India, especially in connection with prevalence of malaria.

\section{HAEMOGLOBIN}

Haemoglobin is a tetramer that consists of two $\alpha$-like and two $\beta$-like globin subunits. These subunits are encoded by two clusters of genes each of which is expressed sequentially during development. The earliest embryonic haemoglobin tetramer, Gower 1 , consists of $\varepsilon$ ( $\beta$-like) and $\zeta(\alpha$-like $)$ polypeptide chains. Beginning at approximately eight weeks of gestation the embryonic chains are gradually replaced by the adult $\alpha$-globlin chain and two different foetal blike chains, designated ${ }^{G} \gamma$ and ${ }^{A} \gamma$. During the transition period between embryonic and foetal development, HB Gower $2\left(\alpha_{2} \varepsilon_{2}\right)$ and HB Portland $\left(\zeta_{2} \gamma_{2}\right)$ are detected. HB F $\left(\alpha_{2} \gamma_{2}\right)$ eventually becomes the predominant $\mathrm{HB}$ tetramer throughout the remainder foetal life. Beginning just prior to birth, the $\gamma$-globin chains are gradually replaced by the adult $\beta$-and $\delta$-globin polypeptides. At six months after birth 97-98 per cent of the haemoglobin is $A_{1}\left(\alpha_{2} \beta_{2}\right)$, while $A_{2}\left(\alpha_{2} \delta_{2}\right)$, accounts for approximately 2 per cent. Small amounts of HB F (1 per cent) are also found in adult peripheral blood (Deisseroth et al. 1978; Embury et al. 1980; Maniatis et al. 1980). The loci for $\mathrm{HB}$ are assigned for haemoglobin alpha to chromosome 16 (16p13.3) and for haemoglobin beta, haemoglobin delta, haemoglobin gamma to chromosome 11 (11p.15.5).

\section{Haemoglobin Variants}

Normal adult human haemoglobin is composed of two different portions which can be separated by electrophoresis techniques; the major portion is called haemoglobin $\mathrm{A}_{1}$ and the minor portion haemoglobin $\mathrm{A}_{2}$. The difference between haemoglobin $A$ and a number of aberrant human haemoglobins is a single amino acid substitution in the $\alpha$ or $\beta$ or $\gamma$ or $\delta$ chain. Most of the mutant haemoglobins have been demonstrated to be under simple genetic control. A number of haemoglobins variant are associated with or produce clinical signs. Over 470 abnormal forms of haemoglobin have been described in the literature. Of them, one third are on the alpha $(\alpha)$ chain, the remaining being mostly on the beta $(\beta)$ chain and a few on the gamma $(\gamma)$ and delta $(\delta)$ chains. The term 'haemoglobinopathies' covers the group of hereditary abnormalities in which the structure (e.g. HB S, HB C, HB D, HB E) or the rate of synthesis (thalassaemia) of normal haemoglobin is altered.

A close concordance between the geographic distribution of endemic malaria and that of high frequency haemoglobin variants, thalassaemias and other red cell defects have been observed which represents one of the principal factors leading to the general acceptance of the malaria hypothesis i.e., in a malarial environment, selective forces have acted to preserve heterozygotes of haemoglobin variants because of their advantage against malarial infection (Allison 1954 a,b, 1964; Livingstone 1957, 1967, 1971, 1983; Rucknagel and Neel 1961; Motulsky 1964; Durham 1983). The selective resistance of the heterozygote illustrates the concept of balanced polymorphism and may be contributory to the maintenance of high allele frequency in a particular area. It is possible that there are still other factors that maintain this genetic equilibrium.

The general incidence of haemoglobin variants has been observed about 0.5 per cent from the Indian region. The abnormal haemoglobins observed among various population groups are HBS, HB E and HB D. The relatively rare abnormal haemoglobins reported from this region are $\mathrm{HB}$ J, $\mathrm{HB} \mathrm{K}, \mathrm{HB} \mathrm{L}, \mathrm{HB} \mathrm{M}, \mathrm{HB}$ Q, HB Lepore, HB Norfolk and the hereditary persistence of HB F. There are two principal types of thalassaemia namely alpha and beta. Beta thalassaemia is of two types: (i) Beta-thalassaemia major on which studies are available from all over India and (ii) Beta-thalassaemia minor, which is mostly reported from north and east India. Alpha thalassaemia is present in two forms: (i) Haemoglobin Barts and (ii) Haemoglobin $\mathrm{H}$. 


\section{Haemoglobin $S$}

One of the most interesting human haemoglobin mutant has been designated $\mathrm{S}$, $\mathrm{Hb}_{2}^{\mathrm{A}} \beta_{2}^{\mathrm{S}}$. The notation signifies that the mutation has affected the $\beta$-chain. In homozygous individuals $\mathrm{Hb} \alpha_{2}^{\mathrm{A}} \beta_{2}^{\mathrm{S}}$ and small amount of $\mathrm{Hb} \alpha_{2}^{\mathrm{A}} \delta_{2}^{\mathrm{A}_{2}}$ are found. In heterozygous individuals three components are found $\mathrm{Hb} \alpha_{2}^{\mathrm{A}} \beta_{2}^{\mathrm{A}}, \mathrm{Hb} \alpha_{2}^{\mathrm{A}} \beta_{2}^{\mathrm{S}}$ and $\mathrm{Hb} \alpha_{2}^{\mathrm{A}} \boldsymbol{\delta}_{2}^{\mathrm{A}}$. Haemoglobin $\mathrm{S}$ may be separated from haemoglobin A by electrophoresis or by performing sickling test on fresh blood. The sickling of red cells of homozygotes (Hb SS$H B * S / H B * S)$ is more severe than that of heterozygotes (HB AS $-H B * A / H B * S$ ).

Genetic load of sickle cell anemia is indeed very high affecting not only the health and physical performance but poses also a challenge to the health services. It is estimated that 186096 cases of sickle cell anemia are present in the Indian sub-continent. Each patient is not only burden on the health services but also affects normal family life (Bhatia, 1987).

The sickle cell trait occurs with highest frequency in tropical Africa (0.100 to 0.400), with high frequency in India, Greece and Southern Turkey (0.050 to 0.100$)$ and less than 0.100 among the population groups living around the Mediterranean Sea (Palestine, Tunisia, Algeria and Sicily) and shows a distribution continuous throughout these areas.

Among the problems which the abnormal haemoglobins present is the one of interaction of alleles for the b-chain variants. Haemoglobin $\mathrm{S}$ is also known to occur with other abnormal haemoglobins. They are: Sickle cell HB C $(H B * S /$ $\left.H B^{*} C\right)$, Sickle cell HB D $\left(H B^{*} S / H B * D\right)$, Sickle cell HB E $\left(H B^{*} S / H B * E\right)$, Sickle cell Thalassaemia $(H B * S / b * T H A L)$, Sickle cell associated with foetal haemoglobin other than during infancy.

With regard to the origin of sickle cell gene, there has been much debate whether the extensive geographical occurrence of sickle-cell disease can be explained by a single origin of the mutation with subsequent large scale migration in prehistoric times or whether it relates to multicentric origins (Lehmann 1953; 1954a,b, 1956-57; Lehmann and Cutbush 1952 a,b; Lehmann et al. 1956; Livingstone 1967). These queries have been examined by an analysis of restriction site polymorphisms (RFLPs) linked to $H B * S$ globin gene; Kan and Dozy (1980) observed differences in the association of sickle cell gene which constituted a base for the hypothesis of multiple mutation origin of $H B * S$. Subsequently studies of an array of RFLPs linked to the $H B * S$ mutation in Jamaicans (Wainscoat et al. 1983; Antonarakis et al. 1984), U.S. Americans (Antonarakis et al. 1984) and African Blacks (Pagnier et al. 1984) strongly supported the hypothesis that the $H B * S$ mutation has arisen independently on several occasions in Africa. The distribution of the different $H B * S$ haplotypes among six different population groups of Africa and Asia by Kalozik et al. (1986) provided strong evidence for an independent Asian origin of mutation. Migration of West African population carrying $H B * S$ Mutation to North Africa, the Mediterranean and West Saudi Arabia is suggested from the analysis but no haplotype has been found by them in their Indian and East Saudi Arabian samples that predominantly showed the major Asian $H B * S$ mutation. They further added that whether the Asian $H B * S$ mutation originated in East Saudi Arabia and spread to India possibly with the Arab expansion in the first millennium A.D. (Bowles 1977) as suggested previously (Lehmann et al. 1963) or vice versa, possibly carried by Indian Arabic trade routes (Bowles 1977) is not known. They concluded that the geographical distribution of Asian $H B * S$ haplotype as observed by them corresponds to the reported distribution of mild homozygous SS $(H B * S$ ) $H B * S)$ disease associated with high levels of HB F (Ali 1970; Haghsenass et al. 1977; Pembrey et al. 1978; Perrine et al. 1978; Brittenham et al. 1979; Weatherall and Clegg 1981; Acquaye et al. 1985; Bakioglu et al. 1985).

The HB S trait is prevalent in Africa with lesser frequencies in the Mediterranean basin, Saudi Arabia and also in India where average frequency $H B * S$ is 0.031 . Geographic and climatic factors have been suggested as determinants for the understanding the observed variations (Charmot and Lefevre-Witier 1978; Lefevre-Witier 1985). The frequency of $H B * S$ is highest in the peninsular plateau (0.039), whereas in other natural regions, it is either absent or present in a very low frequency (Table 2). The frequency of $H B^{*} S$ is quite high in semiarid steppe type region (0.071) followed by tropical savannah type region (0.039) as compared to monsoon type with dry winters region (0.003) (Bhasin et al. 1994; Bhasin and Walter 2001).

It was in the Nilgiri Hills that sickle cell trait 
was first detected in India (Lehmann and Cutbush 1952a, b, c) and among Indian populations the frequency of this trait is 0.031 (varies from complete absence to 0.410 ). It is present in high frequency among the scheduled tribes (0.054) as compared to other ethnic groups -caste (negligible), scheduled caste (0.024) and community $(0.011)$. The trait is reported to be present among scheduled castes and communities, who are living in close proximity with tribal populations. Therefore the trait has been transmitted among these groups due to admixture with tribal groups. In North India, the trait is absent, except sporadic incidences, which may be due to admixture or traces of the past populations who have migrated or displaced by other populations.

The numerous tribal populations inhabiting Rajasthan and West India zone are known by the generic term 'Bhil'. Sickle cell trait is present among all of them, but the regional variation in the frequencies of the trait is very large (varies from complete absence to 0.167 ). The presence of sickle cell trait in the Parsis of Bombay indicates admixture with the neighbouring tribes of Gujarat and Maharashtra (Undevia et al. 1972). This observation is consistent with the presence of $G M^{*} 1,5,13,14$ haplotype and G-6-PD deficiency among Parsis.

From Central India (Madhya Pradesh) among 'Gond' group of tribal populations the frequency of sickle cell trait in general varies from 0.10 to 0.14 . Eastern India inhabited by the Kol/Munda group of populations (Kol, Munda, Ho, Bhuniya, Kharia, Santal, Khairwar, Chero, Bhumij etc.) is characterised by general absence of sickle cell trait. In addition to Kol/Munda group of populations Eastern India is also inhabited by Gond/Khond in Orissa among whom the trait is present; the trait is present in quite high frequency among the tribals from Koraput district of Orissa. From the Eastern Himalayan region sickle cell trait is almost absent except in the state of Assam where $H B^{*} S$ incidence is reported amongst the tea garden workers (Batabyal and Wilson 1958; Dunlop and Mozumdar 1952). It has been ascribed to the origin of these population groups mainly in Orissa, where $H B * S$ is not uncommon followed by migration to Assam (Roy and Roy Chaudhuri 1967). Flatz et al. (1972) have suggested that the $H B * S$ allele is being introduced into the general Assamese population due to the current lowering of social barriers.
Unlike the Bhil, Gond and Kol/Munda groups of Western, Central and Eastern India, there is no such embracing generic term to signify the tribals of Southern India, though this area is inhabited by a large number of small tribal populations. In between the areas of Nilgiri Hills and Wynad plateau, among the tribal populations-Kurumba, Irula, Paniyan, Yerava, Soliga, Adiyan etc., the frequency of sickle cell trait is quite high (varies from 0.18 to 0.32 ) as compared to Jenu Kurumba, Betta Kurumba, Muduga, Malasaar, Badagas and Todas among whom the frequencies are quite low (varies from 0.03 to 0.08 ), while the allele is almost absent among Kotas of Nilgiri and Paliyar and Paliyan of Palni, Kadar of Anamalai and Kanikar, Malapantram, Kuruvan, Ulladan of Cardamon Hills although these areas were hyperendemic for malaria. The $\mathrm{HbS}$ trait is present among Siddis of African desent, whereas it is absent among Andamanese (Negrito) of Andaman Islands. Among Nicobarese with Mongoloid affinity of Nicobar Islands the trait is also absent.

The sickling allele is, therefore, spread over the Central Belt from Gujarat through Madhya Pradesh to Orissa in East and over the Western tract from Gujarat through Maharashtra to South of Kerala. Gene flow for $H B * S$, however, showed a decline from South to North, but not from East to West (Fig. 2).

The correlations of frequencies of sickle cell with various climatic factors and altitude by different ethnic groups show significant differences but these are not high (Table 4).

Among the occupational groups the sickle cell trait is absent among the warfare, trade and commerce, and priesthood groups, i.e., among higher caste groups, whereas the frequency of $H B^{*} S$ is high among the menial workersscheduled castes (0.037); the trait has been transmitted among them due to admixture with tribal groups, who were living in close proximity (Bhasin et al. 1994; Bhasin and Walter 2001).

The $H B * S$ allele is absent among the speakers of Mon Khmer group of Austro-Asiatic, different groups of Indo-European and Pahari group of Indo-European langauges from the Himalayan region, most of which are having Mongoloid affinities. The trait is either absent (Bihari group of Indo-European family) or present in very low frequency (0.010) among Munda group of Austro-Asiatic speakers as compared to IndoEuropean and Dravidian languages speakers (0.027 and 0.047 , respectively). 
Table 2: Haemoglobin system (Allele Frequencies)

\begin{tabular}{|c|c|c|c|c|c|c|c|c|c|c|c|}
\hline \multirow[t]{2}{*}{ Particulars } & \multirow{2}{*}{$\begin{array}{c}\text { Subjects } \\
\text { studied }\end{array}$} & \multirow{2}{*}{$\begin{array}{l}\text { No. of } \\
\text { studies }\end{array}$} & \multicolumn{3}{|c|}{ Frequency $H B^{*} A$} & \multicolumn{3}{|c|}{ Frequency $H B^{*} S$} & \multicolumn{3}{|c|}{ Frequency $H B^{*} E$} \\
\hline & & & Mean & Min & $\operatorname{Max}$ & Mean & Min & $\operatorname{Max}$ & Mean & Min & $\operatorname{Max}$ \\
\hline \multicolumn{12}{|l|}{ 1. NATURAL REGION } \\
\hline Himalayan Mountain Complex & 2778 & 25 & 0.987 & 0.909 & 1.000 & 0.000 & 0.000 & 0.000 & 0.013 & 0.000 & 0.091 \\
\hline Indus-Ganga-Brahmaputra Plains & 9578 & 48 & 0.883 & 0.354 & 1.000 & 0.004 & 0.000 & 0.113 & 0.114 & 0.000 & 0.646 \\
\hline Peninsular Plateau & 47999 & 296 & 0.956 & 0.465 & 1.000 & 0.039 & 0.000 & 0.410 & 0.005 & 0.000 & 0.535 \\
\hline Islands & 181 & 2 & 1.000 & 1.000 & 1.000 & 0.000 & 0.000 & 0.000 & 0.000 & 0.000 & 0.000 \\
\hline \multicolumn{12}{|l|}{ 2. CLIMATIC REGION } \\
\hline $\begin{array}{l}\text { Monsoon Type with Short Dry } \\
\text { Season }\end{array}$ & 2683 & 21 & 0.970 & 0.806 & 1.000 & 0.030 & 0.000 & 0.194 & 0.000 & 0.000 & 0.000 \\
\hline Monsoon Type with Dry Season & 3827 & 16 & 0.988 & 0.815 & 1.000 & 0.012 & 0.000 & 0.185 & 0.000 & 0.000 & 0.000 \\
\hline Tropical Savannah Type & 35957 & 218 & 0.961 & 0.590 & 1.000 & 0.039 & 0.000 & 0.410 & 0.000 & 0.000 & 0.000 \\
\hline Semi Arid Steppe Type & 4968 & 35 & 0.929 & 0.600 & 1.000 & 0.071 & 0.000 & 0.400 & 0.000 & 0.000 & 0.000 \\
\hline Hot Desert Type & - & 0 & - & - & - & - & - & - & - & - & 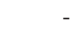 \\
\hline Monsoon Type with Dry Winters & 13101 & 81 & 0.892 & 0.354 & 1.000 & 0.003 & 0.000 & 0.113 & 0.105 & 0.000 & 0.646 \\
\hline $\begin{array}{l}\text { Cold Humid Winters with Short } \\
\text { Summers }\end{array}$ & - & 0 & - & - & - & - & - & - & - & - & . \\
\hline Polar Type & - & 0 & - & - & - & - & - & - & - & - & - \\
\hline \multicolumn{12}{|c|}{ 3. POLITICAL DIVISION OF INDIA } \\
\hline I. NORTH INDIA & & & & & & & & & & & \\
\hline \multicolumn{12}{|l|}{ A. Western Himalaya (S. No. 1, 2) } \\
\hline 1. Jammu and Kashmir & - & 0 & - & - & - & - & - & - & - & - & - \\
\hline 2. Himachal Pradesh & - & 0 & - & - & - & - & - & - & - & - & - \\
\hline 3. Punjab & 494 & 3 & 1.000 & 1.000 & 1.000 & 0.000 & 0.000 & 0.000 & 0.000 & 0.000 & 0.000 \\
\hline 4. Chandigrah UT & 114 & 1 & 0.989 & 0.989 & 0.989 & 0.011 & 0.011 & 0.011 & 0.000 & 0.000 & 0.000 \\
\hline 5. Haryana & - & 0 & - & - & - & - & - & - & - & - & 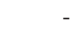 \\
\hline 6. Delhi UT & - & 0 & - & - & - & - & - & - & - & - & - \\
\hline \multicolumn{12}{|c|}{ B. Central Himalaya (S. No. 7, Eight Districts of Uttar Pradesh) } \\
\hline 7. Uttar Pradesh & 3237 & 8 & 0.989 & 0.887 & 1.000 & 0.010 & 0.000 & 0.113 & 0.001 & 0.000 & 0.005 \\
\hline 8. Rajasthan & 343 & 3 & 0.917 & 0.882 & 0.951 & 0.083 & 0.049 & 0.118 & 0.000 & 0.000 & 0.000 \\
\hline II. WEST INDIA & & & & & & & & & & & \\
\hline 9. Gujarat & 4281 & 30 & 0.935 & 0.833 & 1.000 & 0.065 & 0.000 & 0.167 & 0.000 & 0.000 & 0.000 \\
\hline 10. Maharashtra & 17342 & 84 & 0.977 & 0.857 & 1.000 & 0.023 & 0.000 & 0.143 & 0.000 & 0.000 & 0.000 \\
\hline 11. Goa, Daman and Diu UT & 601 & 2 & 0.999 & 0.999 & 1.000 & 0.001 & 0.000 & 0.001 & 0.000 & 0.000 & 0.000 \\
\hline 12. Dadra and Nagar Haveli UT & 276 & 3 & 0.920 & 0.886 & 0.982 & 0.080 & 0.018 & 0.014 & 0.000 & 0.000 & 0.000 \\
\hline III. EAST INDIA & & & & & & & & & & & \\
\hline C. Eastern Himalaya (S. No. 13 & and $L$ & $\lg$ & is & $m$ & & & & & & & \\
\hline 13. Arunachal Pradesh & - & 0 & - & - & - & - & - & - & - & - & - \\
\hline 14. Assam & 3506 & 23 & 0.697 & 0.354 & 0.949 & 0.000 & 0.000 & 0.005 & 0.303 & 0.051 & 0.646 \\
\hline 15. Nagaland & - & 0 & - & - & - & - & - & - & - & - & - \\
\hline 16. Manipur & 417 & 3 & 0.934 & 0.909 & 0.968 & 0.000 & 0.000 & 0.000 & 0.066 & 0.032 & 0.091 \\
\hline 17. Mizoram & - & 0 & - & - & - & - & - & - & - & - & - \\
\hline 18. Tripura & - & 0 & - & - & - & - & - & - & - & - & - \\
\hline 19. Meghalaya & 708 & 6 & 0.637 & 0.465 & 0.802 & 0.000 & 0.000 & 0.000 & 0.363 & 0.198 & 0.535 \\
\hline 20. Sikkim & 1080 & 20 & 0.994 & 0.953 & 1.000 & 0.000 & 0.000 & 0.000 & 0.006 & 0.000 & 0.047 \\
\hline 21. West Bengal & 3508 & 15 & 0.992 & 0.981 & 1.000 & 0.001 & 0.000 & 0.006 & 0.007 & 0.000 & 0.019 \\
\hline 22. Bihar & 1321 & 12 & 0.999 & 0.992 & 1.000 & 0.001 & 0.000 & 0.008 & 0.000 & 0.000 & 0.000 \\
\hline 23. Orissa & 1506 & 10 & 0.954 & 0.860 & 1.000 & 0.046 & 0.000 & 0.140 & 0.000 & 0.000 & 0.000 \\
\hline IV. CENTRAL I & & & & & & & & & & & \\
\hline 24. Madhya Pradesh & 4514 & 39 & 0.939 & 0.800 & 1.000 & 0.061 & 0.000 & 0.200 & 0.000 & 0.000 & 0.000 \\
\hline $\begin{array}{l}\text { V. SOUTH IN } \\
\text { 25. Karnataka }\end{array}$ & & & & & & & & & & & \\
\hline $\begin{array}{l}\text { 25. Karnataka } \\
\text { 26. Andhra Prad }\end{array}$ & & $\begin{array}{r}9 \\
36\end{array}$ & & & $\begin{array}{l}1.000 \\
1.000\end{array}$ & & & & & & 000 \\
\hline $\begin{array}{l}\text { 26. Andhra Prades } \\
\text { 27. Tamil Nadu }\end{array}$ & 6282 & 36 & 0.953 & 0.815 & 1.000 & $\begin{array}{l}0.030 \\
0.047\end{array}$ & 0.000 & 0.185 & 0.000 & 0.000 & 0.000 \\
\hline 28. Kerala & 3028 & 26 & 0.955 & 0.806 & 1.000 & 0.045 & 0.000 & 0.194 & 0.000 & 0.000 & 0.000 \\
\hline 29. Pondicherry UT & - & 0 & - & - & - & - & - & - & - & - & \\
\hline VI. ISLA & & & & & & & & & & & \\
\hline 30. Laksl & - & 0 & - & - & - & - & - & - & - & - & \\
\hline 31. Andr & 68 & 1 & 1.000 & 1.000 & 1.000 & 0.000 & 0.000 & 0.000 & 0.000 & 0.000 & 0.000 \\
\hline Nicobar Islands UT & 113 & 1 & 1.000 & 1.000 & 1.000 & 0.000 & 0.000 & 0.000 & 0.000 & 0.000 & 0.000 \\
\hline 3A. ZON & & & & & & & & & & & \\
\hline I. North India & 4188 & 15 & 0.985 & 0.882 & 1.000 & 0.015 & 0.000 & 0.118 & 0.001 & 0.000 & 0.005 \\
\hline II. West India & 22500 & 119 & 0.989 & 0.833 & 1.000 & 0.031 & 0.000 & 0.167 & 0.000 & 0.000 & 0.000 \\
\hline III. East India & 12046 & 89 & 0.880 & 0.354 & 1.000 & 0.006 & 0.000 & 0.140 & 0.114 & 0.000 & 0.646 \\
\hline IV. Central India & 4514 & 39 & 0.939 & 0.800 & 1.000 & 0.061 & 0.000 & 0.200 & 0.000 & 0.000 & 0.000 \\
\hline V. South India & 17107 & 107 & 0.954 & 0.590 & 1.000 & 0.046 & 0.000 & 0.410 & 0.000 & 0.000 & 0.000 \\
\hline VI. Islands & 181 & 2 & 1.000 & 1.000 & 1.000 & 0.000 & 0.000 & 0.000 & 0.000 & 0.000 & 0.000 \\
\hline INDIA (TOTAL) & 60536 & 371 & 0.946 & 0.354 & 1.000 & 0.031 & 0.000 & 0.410 & 0.023 & 0.000 & 0.646 \\
\hline
\end{tabular}


Table 2: Contd........

\begin{tabular}{|c|c|c|c|c|c|c|c|c|c|c|c|}
\hline \multirow[t]{2}{*}{ Particulars } & \multirow{2}{*}{$\begin{array}{c}\text { Subjects } \\
\text { studied }\end{array}$} & \multirow{2}{*}{$\begin{array}{c}\text { No. of } \\
\text { studies }\end{array}$} & \multicolumn{3}{|c|}{ Frequency $H B^{*} A$} & \multicolumn{3}{|c|}{ Frequency $H B^{*} S$} & \multicolumn{3}{|c|}{ Frequency $H B^{*} E$} \\
\hline & & & Mean & Min & $\operatorname{Max}$ & Mean & Min & $\operatorname{Max}$ & Mean & Min & $\operatorname{Max}$ \\
\hline \multicolumn{12}{|l|}{ 3B. REGIONS OF HIMALAYA } \\
\hline A. Western Himalaya & - & 0 & - & - & - & - & - & - & - & - & 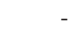 \\
\hline B. Central Himalaya & 1281 & 2 & 0.999 & 0.999 & 1.000 & 0.000 & 0.000 & 0.000 & 0.001 & 0.000 & 0.001 \\
\hline C. Eastern Himalaya & 5711 & 52 & 0.763 & 0.354 & 1.000 & 0.000 & 0.000 & 0.005 & 0.237 & 0.000 & 0.646 \\
\hline HIMALAYA (TOTAL) & 6992 & 54 & 0.806 & 0.354 & 1.000 & 0.000 & 0.000 & 0.005 & 0.193 & 0.000 & 0.646 \\
\hline NON-HIMALAYAN REGIONS & 53544 & 317 & 0.964 & 0.590 & 1.000 & 0.035 & 0.000 & 0.410 & 0.000 & 0.000 & 0.019 \\
\hline \multicolumn{12}{|l|}{ 4. ETHNIC GROUP } \\
\hline \multicolumn{12}{|l|}{ A. ZONES OF INDIA } \\
\hline \multicolumn{12}{|l|}{ 1. NORTH INDIA } \\
\hline Caste & 976 & 4 & 0.999 & 0.995 & 1.000 & 0.000 & 0.000 & 0.000 & 0.001 & 0.000 & 0.005 \\
\hline Scheduled Caste & 1112 & 3 & 0.970 & 0.887 & 0.999 & 0.029 & 0.000 & 0.113 & 0.001 & 0.000 & 0.001 \\
\hline Scheduled Tribe & 274 & 3 & 0.920 & 0.882 & 1.000 & 0.080 & 0.000 & 0.118 & 0.000 & 0.000 & 0.000 \\
\hline Community & 1826 & 5 & 0.995 & 0.951 & 1.000 & 0.004 & 0.000 & 0.049 & 0.001 & 0.000 & 0.001 \\
\hline \multicolumn{12}{|l|}{ II. WEST INDIA } \\
\hline Caste & 1499 & 12 & 1.000 & 0.999 & 1.000 & 0.000 & 0.000 & 0.001 & 0.000 & 0.000 & 0.000 \\
\hline Scheduled Caste & 6160 & 34 & 0.978 & 0.880 & 1.000 & 0.022 & 0.000 & 0.120 & 0.000 & 0.000 & 0.000 \\
\hline Scheduled Tribe & 7569 & 46 & 0.941 & 0.833 & 1.000 & 0.059 & 0.000 & 0.167 & 0.000 & 0.000 & 0.000 \\
\hline Community & 7272 & 27 & 0.984 & 0.857 & 1.000 & 0.016 & 0.000 & 0.143 & 0.000 & 0.000 & 0.000 \\
\hline \multicolumn{12}{|l|}{ III. EAST INDIA } \\
\hline Caste & 992 & 11 & 0.988 & 0.949 & 1.000 & 0.000 & 0.000 & 0.000 & 0.012 & 0.000 & 0.051 \\
\hline Scheduled Caste & 1048 & 9 & 0.898 & 0.650 & 1.000 & 0.000 & 0.000 & 0.000 & 0.102 & 0.000 & 0.350 \\
\hline Scheduled Tribe & 5809 & 43 & 0.853 & 0.354 & 1.000 & 0.013 & 0.000 & 0.140 & 0.134 & 0.000 & 0.646 \\
\hline Community & 4197 & 26 & 0.886 & 0.597 & 1.000 & 0.000 & 0.000 & 0.005 & 0.114 & 0.000 & 0.403 \\
\hline \multicolumn{12}{|l|}{ IV. CENTRAL INDIA } \\
\hline Caste & 350 & 3 & 1.000 & 1.000 & 1.000 & 0.000 & 0.000 & 0.000 & 0.000 & 0.000 & 0.000 \\
\hline Scheduled Caste & 511 & 7 & 0.902 & 0.800 & 0.981 & 0.098 & 0.019 & 0.200 & 0.000 & 0.000 & 0.000 \\
\hline Scheduled Tribe & 3068 & 24 & 0.931 & 0.857 & 1.000 & 0.069 & 0.000 & 0.143 & 0.000 & 0.000 & 0.000 \\
\hline Community & 585 & 5 & 0.975 & 0.877 & 1.000 & 0.025 & 0.000 & 0.123 & 0.000 & 0.000 & 0.000 \\
\hline \multicolumn{12}{|l|}{ V. SOUTH INDIA } \\
\hline Caste & 2094 & 10 & 0.999 & 0.990 & 1.000 & 0.001 & 0.000 & 0.010 & 0.000 & 0.000 & 0.000 \\
\hline Scheduled Caste & 3029 & 13 & 0.997 & 0.858 & 1.000 & 0.023 & 0.000 & 0.142 & 0.000 & 0.000 & 0.000 \\
\hline Scheduled Tribe & 9850 & 70 & 0.930 & 0.590 & 1.000 & 0.070 & 0.000 & 0.410 & 0.000 & 0.000 & 0.000 \\
\hline Community & 2134 & 14 & 0.986 & 0.952 & 1.000 & 0.014 & 0.000 & 0.048 & 0.000 & 0.000 & 0.000 \\
\hline \multicolumn{12}{|l|}{ VI. ISLANDS } \\
\hline Caste & - & 0 & - & - & - & - & - & - & - & - & - \\
\hline Scheduled Caste & - & 0 & - & - & - & - & - & - & - & - & - \\
\hline Scheduled Tribe & 181 & 2 & 1.000 & 1.000 & 1.000 & 0.000 & 0.000 & 0.000 & 0.000 & 0.000 & 0.000 \\
\hline Community & - & 0 & - & - & - & - & - & - & - & - & - \\
\hline \multicolumn{12}{|l|}{ INDIA } \\
\hline Caste & 5911 & 40 & 0.997 & 0.949 & 1.000 & 0.000 & 0.000 & 0.010 & 0.002 & 0.000 & 0.051 \\
\hline Scheduled Caste & 11860 & 66 & 0.966 & 0.650 & 1.000 & 0.024 & 0.000 & 0.200 & 0.009 & 0.000 & 0.350 \\
\hline Scheduled Tribe & 26751 & 188 & 0.917 & 0.354 & 1.000 & 0.054 & 0.000 & 0.410 & 0.029 & 0.000 & 0.646 \\
\hline Community & 16014 & 77 & 0.959 & 0.597 & 1.000 & 0.011 & 0.000 & 0.143 & 0.030 & 0.000 & 0.403 \\
\hline
\end{tabular}

\section{B. REGIONS OF HIMALAYA}

A. Western Himalaya

Caste

Scheduled Caste

Scheduled Tribe

Community

B. Central Himalaya

Caste

Scheduled Caste

Scheduled Tribe

Community

C. Eastern Himalaya

Caste

Scheduled Caste

$\begin{array}{llllllll}\text { Scheduled Tribe } & 2380 & 19 & 0.673 & \mathbf{0 . 3 5 4} & 1.000 & \mathbf{0 . 0 0 0} & 0.000\end{array}$

$\begin{array}{lllllllll}\text { Community } & 2352 & 21 & 0.805 & \mathbf{0 . 5 9 7} & 1.000 & \mathbf{0 . 0 0 0} & 0.000\end{array}$

5. TRADITIONAL OCCUPATION

Priesthood

(3)

$\begin{array}{rrrrrrrrrrr}3239 & 22 & 0.997 & \mathbf{0 . 9 4 9} & 1.000 & \mathbf{0 . 0 0 0} & 0.000 & 0.004 & \mathbf{0 . 0 0 3} & 0.000 & 0.051 \\ 100 & 1 & 1.000 & \mathbf{1 . 0 0 0} & 1.000 & \mathbf{0 . 0 0 0} & 0.000 & 0.000 & \mathbf{0 . 0 0 0} & 0.000 & 0.000\end{array}$

Trade and Commerce

$\begin{array}{lllllllllll}1290 & 10 & 0.997 & \mathbf{0 . 9 8 7} & 1.000 & \mathbf{0 . 0 0 0} & 0.000 & 0.000 & \mathbf{0 . 0 0 3} & 0.000 & 0.013\end{array}$


Table 2: Contd.......

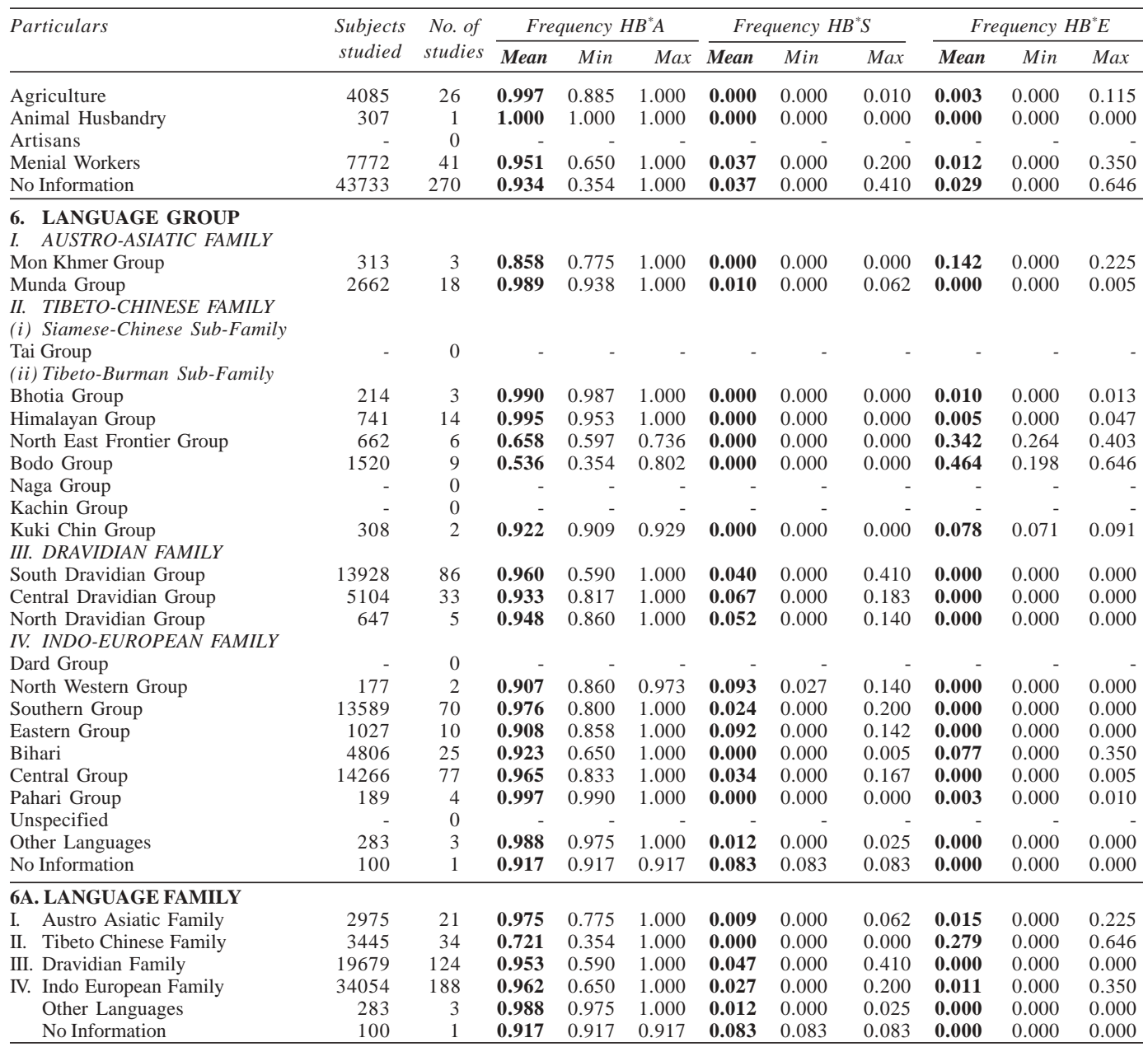

\section{Haemoglobin $\mathbf{E}$}

Unlike haemoglobin $\mathrm{S}$, both the homozygote and heterozygote of haemoglobin $\mathrm{E}$ ( $\beta$ chain variant) are found in healthy individuals. Similarly, those individuals which have a combination of sickle cell and $\mathrm{HB} \mathrm{E}\left(H B^{*} S / H B^{*} E\right)$ also seem to be healthy.

The HBE, first reported in a child whose father was partly of Indian origin, has since then been found in Thailand, Burma, North Eastern Malaya, Indonesia, Assam, Bengal, Nepal, Ceylon and in an Eti-Turk.

The $\beta^{E}$-globin gene is quite common in Southeast Asia (gene frequencies approaching as high as 0.20 to 0.30 ) and presumably it produces mild form of $\beta$-thalassaemia (Orkin et al. 1982) and thereby is under a positive selection in areas in which malaria is endemic. Using restriction analysis multiple origins of $\beta^{E}$ mutation have been pointed out. In fact, $\beta^{E}$ mutation has been observed in five different haplotypes (restriction endonucleases), three in Southeast Asians (Antonarakis et al., 1982) and two in Europeans (Kazaziani et al., 1984). These haploytpes may be found in association with two different $\beta$-globin gene frameworks in Southeast Asians, and a third framework in Europeans. Using restriction analysis at eight restriction sites, Hundrieser et al. (1988a) studied Bodo group - Kachari of Tibeto-Burman languages in Assam among whom highest known prevalence of haemoglobin 


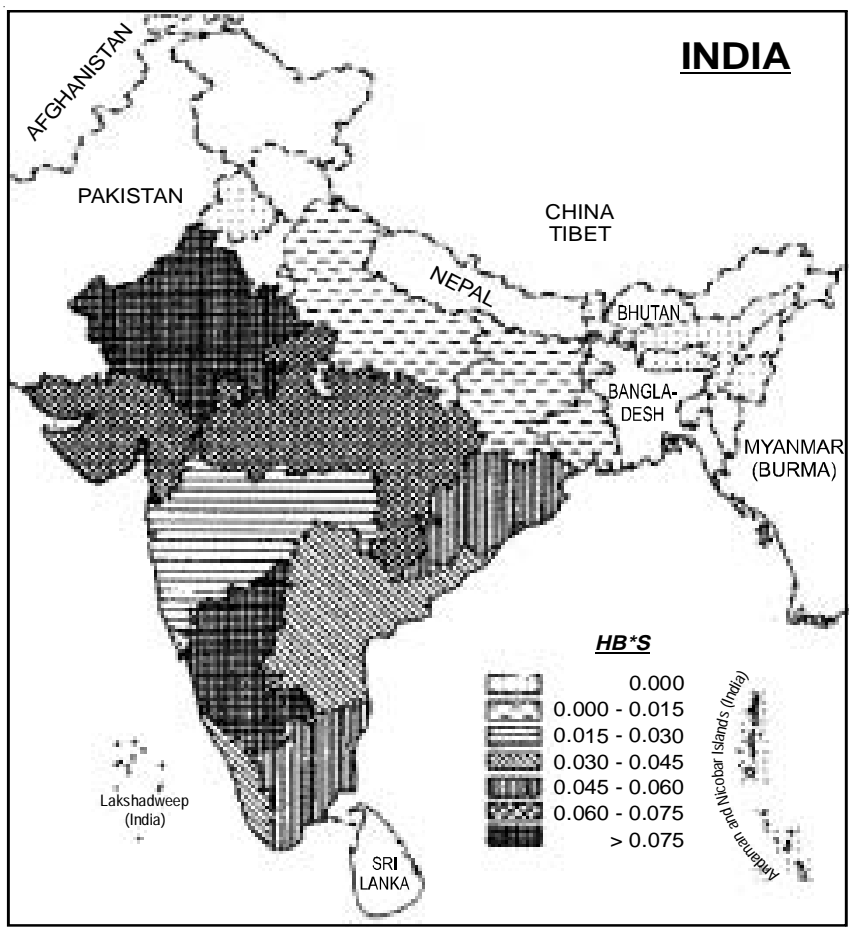

Fig. 2. Allele $H B^{*} S$ of Hemoglobin variants in different regions of India

E has been reported (Das et al. 1988) and found a common origin of the $H B^{*} E$ gene in Southeast Asia and Assam. This was surprising since main area of the distribution of $H B^{*} E$ is Southeast Asia and in contrast other Assamese populations e.g. Ahom and Khasi, the Tibeto-Burman groups have no direct links with Southeast Asians.

The pattern of distribution of $H B^{*} E$ and malarial infection in Southeast Asia and North East India suggests the introduction of $H B^{*} E$ from Southeast Asia and attainment of higher frequencies in certain populations, probably because of continued selective pressure of malarial infection (Saha 1990).

Haemoglobin $\mathrm{E}$, one of the most frequent haemoglobin variants, occurs principally in populations of Southeast Asia. Within this region $H B^{*} E$ has been found with a frequency of nearly 0.60 in some isolated areas (Flatz 1967; Na-Nakorn et al. 1956; Na-Nakorn and Wasi 1978; Wasi et al. 1967; Wasi 1983); the highest incidence occurs at the junction of Laos, Thailand and Cambodia in what has been referred to the the " $H B^{*} E$ Triangle" (Na-Nakron and Wasi 1978). Among Filipinos $H B^{*} E$ is almost absent. In general, all over Indonesia the frequency of $H B^{*} E$ varies from 0.01 to 0.05 and in Malayan population it ranges in between 0.05 and 0.10 with a few exceptions. Among Burmese the overall incidence is around 0.25 to 0.30 . From East Asia, the frequency $H B * E$ is reported 0.01 to 0.02 . It is absent among Tibetans. Among the populations of Southwest Asian region the $H B * E$ has not been observed, except among Iranian, where it is reported about 0.01 . From Indian region, the frequency of $H B^{*} E$ is reported from 0.004 to 0.040 among Nepalies. Its frequency is around 0.01 to 0.05 from Bhutan. The frequency $H B^{*} E$ is less than 0.01 in the populations from Pakistan and it is also observed among Bengali Muslims of Bangladesh. $H B^{*} E$ is present in Bengal and in high frequency in Assam; in other parts of India sporadic cases have been reported. Livingstone (1964) stated that there appears to be a stronger neighbourhood of Calcutta with $H B^{*} E$ predo-minating in the east and $H B^{*} S$ in the west. $H B^{*} E$ was suggested as a marker for the Mongoloid element in Northeast Indian populations (Flatz 1978).

A low frequency of $H B^{*} E$ has been observed among Sinhalese, Tamils and Muslims of 
Sri Lanka by Saha (1988a). Whereas Veddahs in Sri Lanka have been reported to have a high frequency of $H B^{*} E$ (Kirk et al. 1962; Wickremasinghe et al. 1963), Wickremasinghe and Ponnuswamy (1963) found no $H B^{*} E$ in more than 1000 samples of Sinhalese, while De Silva et al. (1959) had reported a high frequency in one locality of Sri Lanka apparently due to admixture with Veddahs in that area. An important feature to note is that the incidence of $H B^{*} E$ is very low and is present in both the Sinhalese and the Tamils of Sri Lanka. Saha stated that this suggests that $H B^{*} E$ has originated with the Veddahs rather than being introduced from Southeast Asia, in which case the incidence should have bene greater in the Sinhalese, contrary to Kirk's (1976) suggestion. $H B^{*} E$ has also occasionally been reported among Europeans (Fairbanks et al. 1979).

In Thailand a reduced fertility of HB E homozygotes $\left(H B^{*} E / H B^{*} E\right)$ compared to that of heterozygotes has been demonstrated (Flatz et al. 1965; Hoflinger 1971). But no differential fertility or mortality in respect of $H B^{*} E$ genotypes among the Kacharis of Upper Assam is observed by Deka (1976). The adaptive advantage of $H B^{*} E$ alleles in areas of endemic malaria in Thailand (Flatz 1967; Kruatrachue et al. 1969) are not detected in Assam (Deka 1976), in spite of wide prevalence of falciparum malaria. Das et al. (1980) observed that these findings appear to corroborate their earlier suggestion (Das et al. 1975 ; Deka 1976) that the $H B^{*} E$ polymorphism in Bodo populations of lower Assam is of transient nature as $H B^{*} E$ allele tends to replace both HB T and HB A.

The frequency of $H B^{*} E$ in Indian populations varies from complete absence to as high as 0.646 among Boro Kachari of Assam with average frequency of 0.023 . Among caste groups the frequency is low (0.002) as compared to other groups-scheduled caste (0.009), scheduled tribe (0.029) and community $(0.030)$. The highest frequency $H B^{*} E$ is observed from Indus-GangaBrahmaputra plains region (0.114) as compared to other regions. From the climatic regions, the $H B^{*} E$ is present only in the monsoon type with dry winters region (0.105) (Bhasin et al. 1994; Bhasin and Walter 2001). The $H B^{*} E$ is observed mainly from East India zone, where frequency is highest among the populations from the state of Meghalaya (0.363, varies from 0.198 to 0.535 ) followed by Assam ( 0.303 , ranges from 0.051 to 0.646 ) as compared to Manipur (0.066, varies between 0.032 and 0.091$)$, Sikkim (0.006, ranges from nil to 0.047) and West Bengal (0.007). A few sporadic cases of $H B^{*} E$ are observed from other areas also (e.g. Uttar Pradesh). In general, $H B^{*} E$ allele is confined to Eastern India, particularly to the Eastern Himalayan populations with Mongoloid affinities in which the frequency is highest among scheduled tribes (0.327), followed by scheduled castes $(0.211)$ and communities $(0.195)$ which shows extensive admixture among these groups as compared to castes among whom the frequency is very low (0.018) (Fig. 3).

Different ethnic groups show correlations of $H B^{*} E$ with mean annual rainfall and mean annual humidity (Table 4). The reasons may be that since these climatic factors are responsible for breeding of vector anopheles responsible for malaria and if $H B^{*} E$ is favoured by selection against malaria, it may attain a high frequency.

The frequency of $H B^{*} E$ allele is high among menial workers $(0.012)$ as compared to other occupational groups among whom the frequency is very low. The presence of allele $H B^{*} E$ among higher occupational groups may be due to admixture (Bhasin et al. 1994; Bhasin and Walter 2001).

The frequency of allele $H B^{*} E$ is observed high in Mon-Khmer group of Austro-Asiatic language family which comprises Cambodia, Vietnam, Mon in Lower Burma, Thailand, Burma, Southern China and East India (Assam and Bengal). $H B^{*} E$ may have emerged in an original Austro-Asiatic group and alongwith the AustroAsiatic language may gradually have diffused throughout mainland South-eastern Asia. However, a quite high frequency of $H B^{*} E$ observed among the speakers of Tibeto-Chinese languages (0.279) from Bodo group (0.464) and North East Frontier group (0.342) in Eastern Himalayan region cannot merely be explained away being introduced into them by AustroAsiatic speakers.

Further heterogeneity of the $H B^{*} E$ allele has recently been observed both in South-East Asia and North-East India (Antonarakis et al. 1982; Hundrieser et al. 1988b).

Although attempts have been made to eradicate malaria from all over the world, yet these have not been successful, especially in India. Whole of the Indian subcontinent is endemic for the malignant falciparum malaria. In India, the vast tracts of land, particularly in Peninsular India, Eastern India (Bihar, Orissa, West Bengal, Assam) and the entire Terai Belt, at the foothills of the 


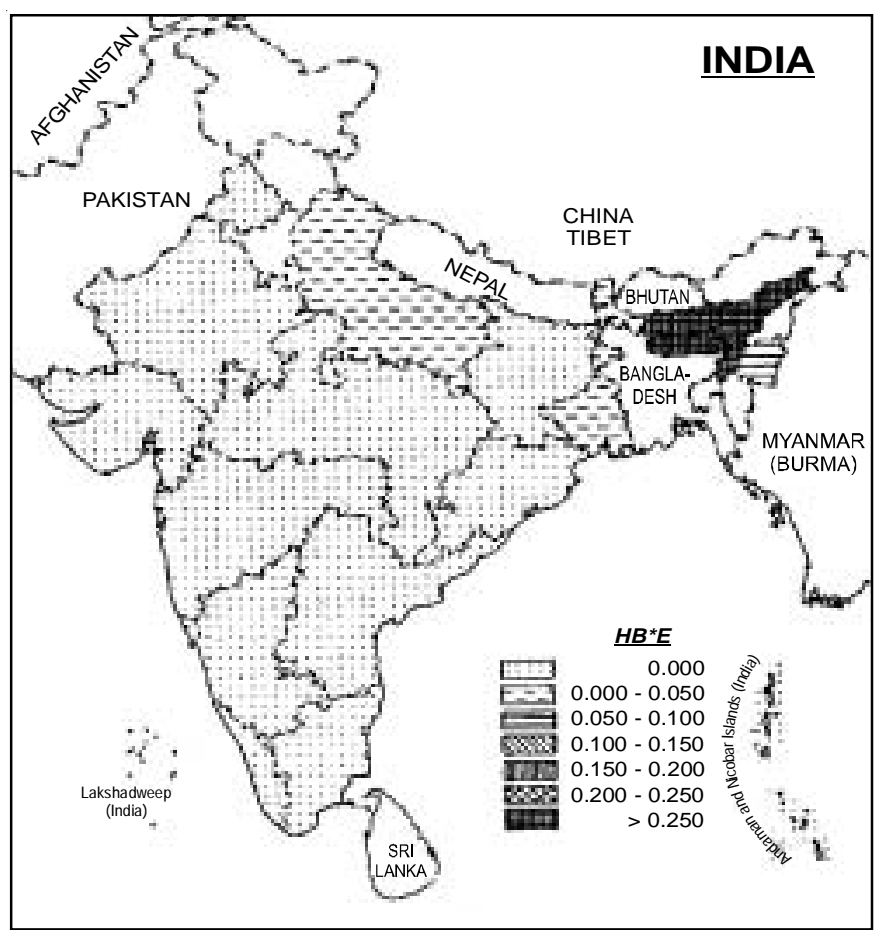

Fig. 3. Allele $H B^{*} E$ of Hemoglobin variants in different regions of India

Himalayan mountain system, had malaria in hyperendemic or endemic conditions Table 3, (Fig. 4). Evidently, sickle cell trait is not found to be present in all these regions. Furthermore, it is also significant that the caste populations all over the country, including highly malarial regions, are also free from this trait. To explain the occurrence of sickle cell trait in West Africa, Livingstone (1958) has marshalled archaeological, linguistic epidemiological and genetic evidences in support of his reconstruction, with the basic premise that malaria is the principle factor which confers resistance on sickle cell heterozygotes. But in India such a reconstruction to explain the maintenance of comparatively high frequencies is not possible, due to great degree of variations in the incidence of the trait among populations sharing the same highly malarious habitat.

A selective advantage of $H B * E$ against malaria in Southeast Asia has been suggested, but could not be corroborated in the Northeast Indian populations so far studied (Deka 1981).

Cruz-Coke (1978) report that no abnormal haemoglobin has been found among the high altitude populations. Is it due to the fact that abnormal haemoglobins carry less oxygen and so they just cannot survive or is it due to absence of malarial parasite in high altitude areas and that the abnormal haemoglobin genes have no selective advantage. Saha (1990) observed a low frequency of $H B^{*} E$ (about 0.02) among Khasis of Cherrapunji district (Meghalaya) as compared to Khasis of Shillong (0.22) and reported that this may be due to relaxation of selection in the absence of malarial infection at high altitude. Saha et al. (1987) have also found a low frequency of $H B^{*} E$ among Lepchas of Darjeeling Hills.

\section{CONCLUSION}

The information available on the abnormal haemoglobins, their frequencies, geographical locations, ethnic groups etc. are not sufficient and complete as observed, therefore it is rather difficult to study the relationship among different factors. That the incidence of G-6-PD deficiency in different populations shows a positive correlation with incidence of abnormal haemoglobin alleles, has been recorded in Southeast Asia and 
Table 3: Species distribution of positive cases encountered state-wise breakup (provisional) alongwith haemoglobins $S$ and $E$ and glucose-6-phosphate dehydrogenase deficiency

\begin{tabular}{|c|c|c|c|c|c|c|c|c|c|}
\hline \multirow{2}{*}{$\begin{array}{l}\text { S. } \\
\text { No. }\end{array}$} & \multirow{2}{*}{$\begin{array}{l}\text { Name of the Zone/Region } \\
\text { State \& Union Territory (U.T.) }\end{array}$} & \multirow[t]{2}{*}{$P V$} & \multicolumn{2}{|c|}{ PF Cases } & \multirow[t]{2}{*}{ Others } & \multirow[t]{2}{*}{ Total } & \multirow[t]{2}{*}{$H B * A S$} & \multicolumn{2}{|c|}{$H b^{*} E G 6 P D * d e f$} \\
\hline & & & $R+$ & $R g+$ & & & & & \\
\hline \multicolumn{10}{|c|}{ I. NORTH INDIA } \\
\hline \multicolumn{10}{|c|}{ A. Western Himalaya (S. No. 1, 2) } \\
\hline 1. J & Jammu and Kashmir & 0.005 & - & - & - & 0.004 & - & - & 0.057 \\
\hline 2. 1 & Himachal Pradesh & 0.018 & - & - & - & 0.015 & - & - & 0.095 \\
\hline 3. I & Punjab & 0.131 & 0.005 & 0.001 & 0.003 & 0.112 & 0.000 & 0.000 & 0.048 \\
\hline 4. & Chandigrah UT & 0.016 & - & - & - & 0.013 & 0.011 & 0.000 & 0.075 \\
\hline 5. 1 & Haryana & 0.174 & 0.003 & 0.088 & 0.017 & 0.149 & - & - & 0.020 \\
\hline 6. I & Delhi UT & 0.043 & 0.0002 & - & - & 0.037 & - & - & 0.025 \\
\hline \multicolumn{10}{|c|}{ B. Central Himalaya (S. No. 7, Eight Districts of Uttar Pradesh) } \\
\hline 7. I & Uttar Pradesh & 0.058 & 0.004 & 0.029 & 0.014 & 0.050 & 0.010 & 0.001 & 0.079 \\
\hline 8. I & Rajasthan & 0.034 & 0.007 & 0.017 & 0.011 & 0.030 & 0.083 & 0.000 & - \\
\hline \multicolumn{10}{|c|}{ II. WEST INDIA } \\
\hline 9. & Gujarat & 0.136 & 0.020 & 0.105 & 0.011 & 0.119 & 0.065 & 0.000 & 0.042 \\
\hline 10.1 & Maharashtra & 0.072 & 0.062 & 0.089 & 0.036 & 0.070 & 0.023 & 0.000 & 0.040 \\
\hline 11. & Goa, Daman and Diu UT & 0.001 & - & - & - & 0.001 & 0.001 & 0.000 & 0.005 \\
\hline 12. I & Dadra and Nagar Haveli UT & - & - & - & - & - & 0.080 & 0.000 & 0.130 \\
\hline \multicolumn{10}{|c|}{ III. EAST INDIA } \\
\hline \multicolumn{10}{|c|}{ C. Eastern Himalaya (S. No. 13 to 20 and Darjeeling District of West Bengal) } \\
\hline 13. & Arunachal Pradesh & 0.008 & 0.020 & 0.037 & 0.138 & 0.010 & - & - & - \\
\hline 14. & Assam & 0.013 & 0.100 & 0.005 & 0.046 & 0.024 & 0.000 & 0.303 & 0.088 \\
\hline & Nagaland & 0.002 & 0.009 & 0.027 & 0.0014 & 0.0044 & - & - & 0.271 \\
\hline 16.1 & Manipur & 0.001 & 0.003 & 0.050 & 0.106 & 0.002 & 0.000 & 0.066 & - \\
\hline 17.1 & Mizoram & 0.003 & 0.026 & 0.019 & 0.015 & 0.007 & - & - & - \\
\hline 18. $T$ & Tripura & 0.0011 & 0.021 & 0.004 & - & 0.004 & - & - & - \\
\hline 19.1 & Meghalaya & 0.0013 & 0.035 & 0.004 & 0.008 & 0.006 & 0.000 & 0.363 & 0.062 \\
\hline 20.5 & Sikkim & 0.00002 & - & - & - & 0.00002 & 0.000 & 0.006 & - \\
\hline 21. & West Bengal & 0.002 & 0.0003 & - & - & 0.0014 & 0.001 & 0.007 & 0.048 \\
\hline $22 . \mathrm{H}$ & Bihar & 0.014 & 0.60 & 0.023 & 0.010 & 0.020 & 0.001 & 0.000 & - \\
\hline 23. & Orissa & 0.042 & 0.429 & 0.148 & 0.137 & 0.098 & 0.046 & 0.000 & 0.110 \\
\hline \multicolumn{10}{|c|}{ IV. CENTRAL INDIA } \\
\hline 24.1 & Madhya Pradesh & 0.070 & 0.143 & - & 0.085 & 0.080 & 0.061 & 0.000 & 0.061 \\
\hline \multicolumn{10}{|c|}{ V. SOUTH INDIA } \\
\hline $25 . \mathrm{H}$ & Karnataka & 0.098 & 0.020 & 0.166 & 0.201 & 0.088 & 0.082 & 0.000 & 0.000 \\
\hline 26. & Andhra Pradesh & 0.018 & 0.019 & 0.076 & 0.067 & 0.019 & 0.038 & 0.000 & 0.036 \\
\hline 27. 7 & Tamil Nadu & 0.037 & 0.002 & 0.098 & 0.069 & 0.033 & 0.047 & 0.000 & 0.071 \\
\hline $28 . \mathrm{r}$ & Kerala & 0.002 & 0.00001 & 0.0001 & 0.001 & 0.0013 & 0.045 & 0.000 & 0.012 \\
\hline 29. F & Pondicherry UT & 0.0002 & - & 0.0002 & - & 0.0001 & - & - & - \\
\hline \multicolumn{10}{|c|}{ VI. ISLANDS } \\
\hline $30 . \mathrm{I}$ & Lakshadweep UT & - & - & - & - & - & - & - & - \\
\hline 31. & $\begin{array}{l}\text { Andman Islands and } \\
\text { Nicobar Islands UT }\end{array}$ & 0.003 & 0.002 & 0.002 & 0.023 & 0.003 & 0.000 & 0.000 & - \\
\hline IND & IA (TOTAL) & & & & & & 0.031 & 0.023 & 0.045 \\
\hline
\end{tabular}

$\mathrm{PV}=$ Plasmodium vivax $\quad \mathrm{PF}=$ Plasmodium falciparum

$\mathrm{R}+$ = Rings and Gametocytes

Mediterranean populations (Siniscalco et al. 1961; Allison et al. 1963; Flatz et al. 1965). The data from India are as yet insufficient for any generalization, however, high incidence of $H B * S$ as well as $G 6 P D^{*}$ def have been observed among scheduled tribes from West, Central and South India (Sukumaran et al. 1956; Vyas et al. 1962; Das et al. 1967; Negi 1968; Kate et al. 1984; Bhatia 1987). Since $G 6 P D *$ def is prevalent in adult population nearly all over India in frequencies varying from less than 0.01 to 0.16 , no significant correlation has been established with any particular haemoglobin variant as yet.

Samuel et al. (1986) observed that the red cell $G 6 P D * d e f$ allele was significantly associated with the sickle cell gene $(H B * S)$ in both males and females and thalassaemias (in males $\alpha$ - and $\beta$ thalassaemias and in females $\beta$-thalassaemia) and concluded that the three commonly occuring inherited red cell defects-G-6-PD, sickle cell and thalassaemia genes-have probably originated as a result of the same selection factor i.e. malarial 
infection. But a selective advantage of $G 6 P D * d e f, H B * E$ and $H B * S$ could not be corroborated in the Indian populations so far studied.

The effect of and relation with various environment factors are as yet uncertain, since the studies wherever available are fragmentary and ambiguous. The interaction of an abnormal gene with other genes and with climate, nutrition, geographical and other environment parameters requires a thorough analysis. Future studies should therefore be conducted with carefully planned sampling techniques, with an understanding of historical, demographic and genealogical relationship of people living in different environmental conditions.

Among Indian populations the incidence of haemoglobin variants is about $0.005 . H B * S$ allele with a frequency ranging from complete absence to 0.410 is present among them with a general frequency of 0.031 . It is prevalent among the scheduled tribe followed by scheduled caste groups but is almost absent in the caste groups. Its frequency is high in semi arid steppe type of climatic region (0.071) as compared to others. It is present in high frequency in Central India followed by South, West and North India. The frequency is quite low in East India and the allele is absent in Islands zone. $H B * S$ frequency is high in Dravidian language family $(0.047)$ but it is lacking in Tibeto-Chinese language family. With regard to the origin of sickle cell gene, Kan and Dozy (1980) proposed the view that Indian and West African sickle cell gene mutations arose by separate events. The $H B^{*} E$ is observed in high frequency among the population groups of East India particularly from Eastern Himalayan region where the frequency is 0.237 . The frequency of $H B^{*} E$ is high in speakers of Mon Khmer group of Austro-Asiatic language family, as well as among the speakers of Tibeto-Chinese language family from Eastern Himalayan region. Heterogeneity of the $H B^{*} E$ allele has been recently observed both in Southeast Asia and North-east India. A selective advantage of $H B * S$ and $H B * E$ against malaria could not be corroborated in the Indian populations. The low frequency of $H B^{*} E$ at high altitude is suggested to be due to relaxation of selection.

It has been observed that most of the studies reported in the literature involve case studies

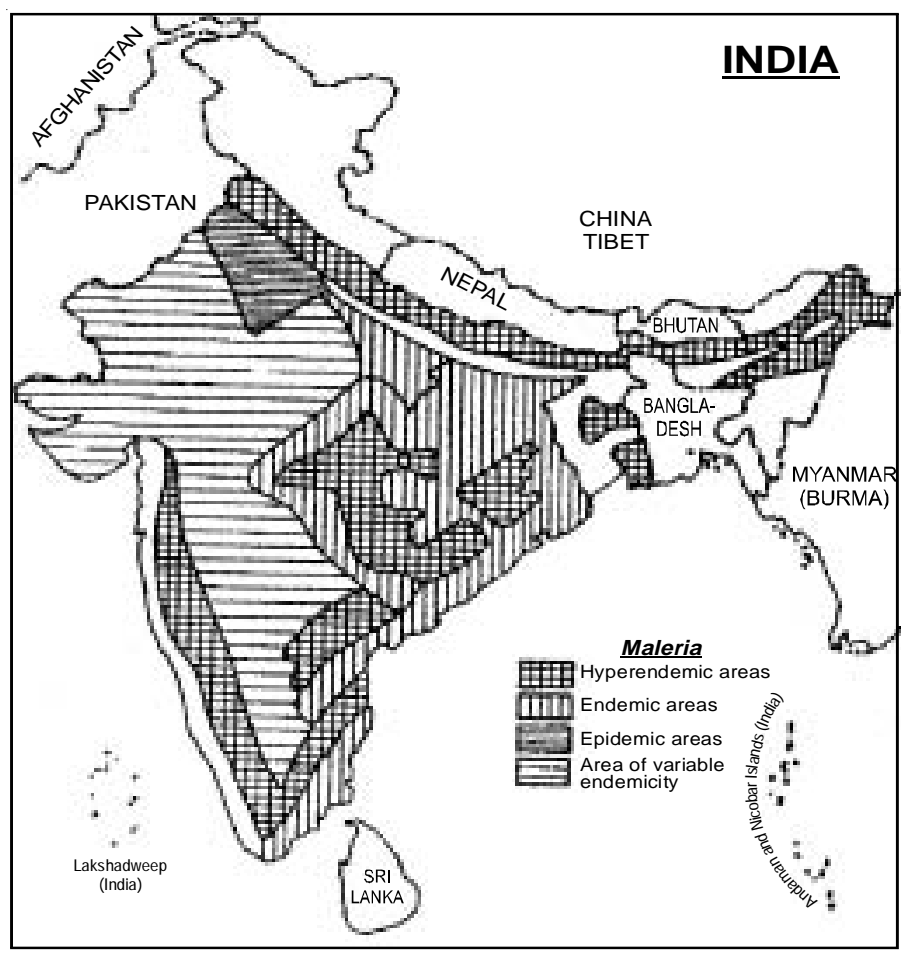

Fig. 3. Maleria in India 
Table 4: Correlation with climatic factors and ethnic groups

\begin{tabular}{|c|c|c|c|c|}
\hline \multirow{2}{*}{$\begin{array}{l}\text { Ethnic } \\
\text { groups }\end{array}$} & \multirow{2}{*}{$\frac{G-6-P D}{G 6 P D * d e f}$} & \multicolumn{3}{|c|}{ Haemoglobin } \\
\hline & & $H B^{*} A$ & $H B * S$ & $H B^{*} E$ \\
\hline \multicolumn{5}{|c|}{ Mean Annual Temperature } \\
\hline Caste & $0.445^{2}$ & 0.139 & 0.078 & -0.209 \\
\hline Scheduled Caste & 0.028 & $0.331^{2}$ & -0.079 & $-0.400^{3}$ \\
\hline Scheduled Tribe & $0.423^{2}$ & 0.075 & 0.152 & -0 \\
\hline Community & 0.063 & $0.315^{2}$ & $0.233^{1}$ & $-0.515^{3}$ \\
\hline Total & $0.295^{3}$ & $0.170^{2}$ & $0.110^{2}$ & $-0.365^{3}$ \\
\hline \multicolumn{5}{|c|}{ Mean Annual Rainfall } \\
\hline Caste & 0.207 & -0.042 & -0.059 & 0.085 \\
\hline eduled Caste & -0. & 0.1 & -0. & $0.312^{1}$ \\
\hline Scheduled Tribe & -0.3 & 0.077 & $-0.244^{3}$ & $0.436^{3}$ \\
\hline$\underline{\text { Comr }}$ & -0.076 & $-0.301^{2}$ & $-0.262^{1}$ & $0.502^{3}$ \\
\hline Total & -0.0 & $-0.134^{2}$ & $-0.195^{3}$ & $0.408^{3}$ \\
\hline \multicolumn{5}{|c|}{ Mean Annual Humidity } \\
\hline s & 0.207 & -0 & 0.126 & -0.056 \\
\hline duled Caste & -0.115 & 16 & -0.011 & $0.339^{2}$ \\
\hline Scheduled Tribe & $-0.317^{1}$ & -0.006 & $-0.238^{2}$ & $0.350^{3}$ \\
\hline nunity & 0.110 & $-0.371^{3}$ & $-0.226^{1}$ & $0.556^{3}$ \\
\hline Total & -0.046 & -0.097 & $-0.194^{3}$ & $0.370^{3}$ \\
\hline \multicolumn{5}{|l|}{ Mean Altitude } \\
\hline & -0.114 & 0.075 & -0.056 & -0.044 \\
\hline luled Caste & 0.097 & 0.069 & 0.153 & $-0.338^{2}$ \\
\hline led Tribe & 0.203 & -0.019 & -0.035 & 0.104 \\
\hline unity & 0.045 & 0.195 & -0.050 & -0.169 \\
\hline Total & 0.017 & -0.023 & 0.069 & -0.063 \\
\hline
\end{tabular}

Significant at $\mathrm{P}<0.001$

and reports from hospital, which cannot be regarded to represent population surveys, as samples studied are heterogeneous. Further, most of the studies have not given any details about the ethnic group, social and environmental factors etc. Therefore it was rather difficult to study the relationship of abnormal haemoglobins with different factors. Carefully designed studies should therefore be planned in the future.

\section{NOTES}

1. Three more states have come into existence recently. Now Bihar has been divided into Bihar and Jharkhanda; from Madhya Pradesh have resulted the states of Madhya Pradesh and Chattisgarh; the earlier state of of Uttar Pradesh is now divided into Uttar Pradesh and Uttaranchal. The states in italics are newer ones. India at present comprises 28 states.

2. The frequency distributions for the State of Goa and Union Teritory of Daman and Diu have been listed under Goa, Daman and Diu.

\section{REFERENCES}

Acquaye JK, Omer A, Ganeshaguru K, Sejeny SA, Hoffbrand AV 1985. Non-benign sickle cell anaemia in western Saudi Arabia. Br J Haematol, 60: 99108

Ali SA 1970. Milder variant of sickle-cell disease in Arabs in Kuwait associated with unusually high level of foetal hemoglobin. Br J Haematol, 19: 613619.

Allison AC 1954a. Protection afforded by sickle-cell trait against subtertian malarial infection. Brit Med, i: $290-294$.

Allison AC 1954b. The distribution of the sickle-cell trait in East Africa and elsewhere, and its apparent relationship to subtertian malaria. Trans Roy Soc Trop Med Hyg, 48: 312-318.

Allison AC 1964. Polymorphism and natural selection in human populations. Cold Spring Harbour Symposia on Quantitative Biology, 29: 137-149.

Allison AC, Askonas BA, Barnicot NA, Blumberg BS, Krimbas C 1963. Deficiency of erythrocyte glucose -6- phosphate dehydrogenase in Greek populations. Ann Hum Genet, 26: 237-242.

Antonarakis SE, Orkin SH, Kazazian HH, Goff SC, Boehm CD, Waber PG, Sexton JP, Ostrer N, Fairbanks VF, Chakravarti A 1982. Evidence for multiple origins of the $\beta E$-globin gene in Southeast Asia. Proc Natl Acad Sci USA, 79: 6608-6611.

Antonarakis SE, Boehm CD, Serjeant GR, Theisen CE, Dover GJ, Kazazian HH Jr 1984. Origin of the BSglobin gene in Blacks: The contribution of recurrent mutation or gene conversion of both. Proc Natl Acad Sci USA, 81: 853-856.

Azevedo E, Kirkman HN, Morrow AC, Motulsky AG 1968. Variants of red cell glucose-6-phosphate dehydrogenase among Asiatic Indians. Ann Hum Genet, 31: 373

Bakioglu I, Hottori Y, Kutlar A, Mathew C, Huisman THJ 1985. Five adults with mild sickle-cell anemia share a $\beta S$-chromosome with the same haplotype. Am J Hematol, 20: 297-300.

Batabyal JN, Wilson JMG 1958. Sickle-cell anaemia in Assam. J Ind Med Assoc, 30: 8-11.

Baxi AJ 1974. Glucose-6-phosphate dehydrogenase deficiency A note on the distribution of gene frequency in India. pp 60-66. In: Human Population Genetics in India. Volume 1 LD Sanghvi, V Balakrishnan, HM Bhatia, PK Sukumaran, JV Undevia (Eds.). Bombay: Orient Longman.

Baxi AJ, Balakrishnan V, Undevia JV, Sanghvi LD 1963. Glucose-6-phosphate dehydrogenase deficiency in the Parsee community, Bombay. Ind J Med Sci, 17: 493-500.

Beutler E. 1975. Human glucose-6 phosphate dehydrogenase deficiency A new Indian variant G-6-PD Jammu. pp 279-293. In: Trends in Hematology. NN Sen, AK Basu (Eds.). Calcutta.

Beutler E 1990. The genetics of glucose-6-phosphate dehydrogenase deficiency. Seminars in Hematology, 27: $137-164$.

Bhasin MK 1988. Biology of the Peoples of Indian Region (Bangladesh, Bhutan, India, Maldives, Nepal, Pakistan, Sri Lanka). A Classified and Comprehensive Bibliography. Delhi: Kamla-Raj Enterprises.

Bhasin MK, Walter H, Danker-Hopfe H 1992. The Ditribution of Genetical, Morphological and Behavioural Traits among the People of Indian 
Region (Bangladesh, Bhutan, India, Maldives, Nepal, Pakistan, Sri Lanka). Delhi: Kamla-Raj Enterprises.

Bhasin MK, Walter H, Danker-Hopfe H 1994. People of India. An Investigation of Biological Variability in Ecological, Ethno-Economic and Linguistic Groups. Delhi: Kamla-Raj Enterprises.

Bhasin MK, Walter H 2001. Genetics of Castes and Tribes of India. Delhi: Kamla-Raj Enterprises.

Bhatia HM 1987. Genetic parameters: Biologic and epidemiology significance. Ind J Med Sci, 41: 203207.

Bowles GT 1977. The People of Asia. London: Weidenfeld and Nicholson.

Brittenham G, Lozoff B, Harris JW, Mayson SM, Miller A, Huisman, THJ 1979. Sickle cell anemia and trait in southern India: Further studies. Am $J$ Hematol, 6: 107-123.

Cavalli-Sforza LL, Piazza A, Menozzi P 1994. The History and Geography of Human Genes. Princeton, New Jersey: Princeton University Press.

Cayani E, Lane AB, Jenkins T, Nurse GT, Balinsky D 1977. Glucose-6-phosphate dehydrogenase Porbander: A new variant with slightly reduced activity in South African family of Indian descent. Biochem Genet, 15: 765-773.

Cruz-Coke R 1978. A genetic description of high altitude populations pp 47-63 In: The Biology of HighAltitude Peoples. PT Baker (Ed.). International Biological Programme 14. Cambridge: Cambridge University Press.

Das BM, Deka R, Flatz G 1975. Predominance of the haemoglobin $\mathrm{E}$ gene in a Mongoloid population in Assam India. Humangenetik, 30: 187-191.

Das BM, Deka R, Das R 1980. Haemoglobin E in six populations of Assam. J Ind Anthrop Soc, 15: 153156.

Das SR, Mukherjee DP, Sastry DB 1967. Sickle cell trait in Koraput district and parts of India. Acta Genet Stat Med, 17: 62-73.

De Silva CC, Jonxis JHP, Wickremasinghe RL 1959. Haemoglobinopathies in Ceylon. pp 340-356 In: Abnormal Haemoglobins. JHP Jonxis, JF Delafresnaye (Eds.). Oxford: Blackwell Scientific Publication.

Deisseroth A, Nienhuis A, Lawrence J, Giles R, Turner P, Ruddle FH 1978. Chromosomal localization of human $\beta$-globin gene in human chromosome 11 in somatic cell hybrids. Proc Natl Acad Sci USA, 75: 1456-1460.

Deka R 1976. Age at menarche and haemoglobin E among the Kachari women of Upper Assam. Man in India, 56: 349-354.

Deka R 1981. Fertility and haemoglobin genotypes: A population study in Upper Assam India. Hum Genet, 59: $135-136$.

Dunlop KJ, Mozumder UK 1952. The occurrence of sickle cell anaemia among a group of the garden labourers in Upper Assam. Ind Med Gaz, 87: 387.

Durham WH 1983. Testing the malaria hypothesis in West Africa. pp 45-72 In: Distribution and Evolution of Haemoglobin and Globin Loci. JE Bowman (Ed.). New York: Elsevier.

Embury SM, Miller JA, Dozy AM, Kan YW, Chan V, Todd D 1980. Two different molecular organizations account for the single $\alpha$-globulin gene of the $\alpha$ thalassemia-2 genotype. J Clin Invest, 66: 13191325 .

Fairbanks VF, Gilchrist GS, Brimhall B, Jereb JA, Goldston EC 1979. Hemoglobin E trait reexamined: A cause of microcytosis and erythrocytosis. Blood, 53: 109115 .

Flatz G 1967. Hemoglobin E: Distribution and population dynamics. Humangenetik, 3: 189-234.

Flatz G 1978. Population dynamics of hemoglobinopathies in South East Asia. pp 191-197. In: Medical Genetics in India. IC Verma (Ed.). Pondicherry: Auroma Enterprises.

Flatz G, Pik C, Robinson GL 1965. Haemoglobin E and $\beta$-thalassemia: Their distribution in Thailand. Ann Hum Genet, 29: 151-170.

Flatz G, Chakravartti MR, Das BM, Delbrück H 1972. Genetic survey in the population of Assam: ABO blood groups, glucose-6-phosphate dehydrogenase and haemoglobin type. Hum Hered, 22: 323.

Gopalan C, Rao BSN 1980. Dietary Allowances for Indians. Special Report Series No 60, Indian Council of Medical Research, New Delhi.

Goshan DT 1979. Study of Blood Groups, Erythrocytic Enzymes, Serum Proteins and Haemoglobin Variants in the Endogamous Castes from Cutch. M. Sc. Thesis, Bombay: University of Bombay.

Haghsenass M, Ismail-Beigi F, Clegg JB, Weatherall DJ 1977. Mild sickle-cell anaemia in Iran associated with high levels of fetal haemoglobin. J Med Genet, 14: $168-171$

Harrison GA, Tanner JM, Pilbeam DR, Baker PT 1988. Human Biology. An Introduction to Human Evolution, Variation, Growth and Adaptability. 3rd Edition, Oxford: Oxford University Press.

Höftlinger H 1971. Die Fortpflanzung von Frauen der drei Genotypen emoglobin A, Häemoglobin A E und Häemoglobin $E$ in tropisch-ländlichem. Bonn: Milieu Dissertation.

Hundrieser J, Deka R, Gogoi BC, Papp T, Flatz G 1988a. DNA haplotypes and frameworks associated with the beta-globin gene in the Kachari population of Assam India Hum Hered, 38: 240-245.

Hundrieser J, Sanguansermsri T, Papp T, Laig M, Flatz G 1988b. $\beta$-globin gene linked DNA haplotypes and frameworks in three South-East Asian populations Hum Genet, 80: 90-94.

Ishwad CS, Naik SN 1984. A new glucose-6-phosphate dehydrogenase variant G-6-PD Kalyan found in a Koli family. Hum Genet, 66: 171-175.

Jolly JG, Sarup BM, Bhatnagar DP, Maini SC 1972. G-6PD deficiency in India. J Ind Med Assoc, 58: 196200.

Kan YW, Dozy AM 1980. Evolution of the hemoglobin $S$ and $C$ genes in world populations Science, 209: 388-391.

Kate SL, Mokashi GD, Khedkar VA, Mukherjee BN 1984. Prevalence of hemoglobin $\mathrm{E}$ in ten population groups of West Bengal, India. Ind J Haematol, 11: 221223.

Kazazian HH, Waber PG, Boehm CD, Lee JI, Antonarakis SE, Fairbanks VF 1984. Hemoglobin E in Europeans: Further evidence for multiple origins of âE-globin gene. Am J Hum Genet, 36: 212-217.

Kirk RL 1976. The legend of Prince Vijaya - a study of 
Sinhalese origins. Am J Phys Anthrop, 45: 91-100. Kirk RL, Lai LYC, Vos GH, Wickremasinghe RL, Perera DJB 1962. The blood and serum groups of selected populations in South India and Ceylon. Am J Phys Anthrop, 20: 485-497.

Kruatrachue M, Bhaibulaya M, Klongkaran-aunkam K, Harinasuta C 1969. Haemoglobinopathies and malaria in Thailand. Bull WHO, 40: 459-463.

Lehmann H 1953. The sickle-cell trait not an essentially Negroid feature. Man, 53: 9.

Lehmann H 1954a. Distribution of sickle-cell gene A new light on the origin of east Africans. Eugen Rev, 46: $101-121$.

Lehmann H 1954b. Origin of sickle-cell. South Afr J Sci, p 140-141.

Lehmann H 1956-57. Variation of haemoglobin synthesis in man. Acta Genet Basel, 6: 413-429.

Lehmann H, Cutbush M 1952a. Sickle-cell trait in southern India. Brit Med J, i: 404-415.

Lehmann H, Cutbush M 1952b. The findings of the sickle-cell trait in Pre-Dravidians of southern India. Man, 53: 10 .

Lehmann H, Cutbush M 1952c. Sub-division of some Southern Indian communities according to the incidence of sickle-cell trait and blood groups. Trans Roy Soc Trop Med Hyg, 46: 380-383.

Lehmann H, Story P, Thein H 1956. Haemoglobin E in Burmese: Two cases of haemoglobin E disease. Brit Med J, i: 544 .

Lehmann H, Maranjian G, Mourant AE 1963. Distribution of sickle-cell haemoglobin in Saudi Arabia. Nature Lond, 198: 492.

Livingstone FB 1957. Sickling and malaria. $\mathrm{Br}$ Med J, 1: 762-763.

Livingstone FB 1958. Anthropological implications of sickle cell gene distribution in West Africa. Am Anthrop, 60: 533-562.

Livingstone FB 1964. The distribution of the abnormal hemoglobin genes and their significance for human evolution. Evolution, 18: 685-699.

Livingstone, FB 1967. Abnormal Hemoglobins in Human Populations A Summary and Interpretation. Chicago: Aldine Publishing Co.

Livingstone FB 1971. Malaria and human polymorphisms. Ann Rev Genet, 5: 33-64

Livingstone FB 1983. The malaria hypothesis pp 15-35 In: Distribution and Evolution of Haemoglobin and Globin Loci. JE Bowman (Ed.). New York.

Luzzatto L, Mehta A 1989. Glucose-6-phosphate dehydrogenase deficiency pp 2237-2265 In: The Metabolic Basis of Inherited Disease. CR Scriver, AL Beaudet, WS Sly, D Valle (Eds.). New York: McGraw Hill, 6th Edition.

Maniatis T, Fritsch EF, Lauer J, Lawn RM 1980. The molecular genetics of human hemoglobins. Ann Rev Genet, 14: 145-178.

Martini G, Toniolo D, Vulliamy T, Luzzatto L, Dono R, Viglietto G, Paonessa G et al 1986. Structural analysis of the $\mathrm{X}$-linked gene encoding human glucose-6-phosphate dehydrogenase. EMBO J, 5: $1849-1855$

Motulsky AG 1964. Hereditary red cell traits and malaria. Am J Trop Med Hyg, 13: 147.

Mourant AE, Kopec AC, Domaniewska-Sobczak K 1976. The Distribution of the Human Blood Groups and
Other Polymorphisms. 2nd Edition, London: Oxford University Press.

Mourant AE, Kopec AC, Domaniewska-Sobczak K 1978. Blood Groups and Diseases. Oxford: Oxford University Press.

Na-Nakorn S, Minnich V, Chernoff AI 1956. Studies of haemoglobin E II The incidence of haemoglobin E in Thailand. J Lab Clinic Medicine, 47: 490-498.

Na-Nahron S, Wasi P 1978. The distribution of HbE: Hemoglobin E triangle in South-East Asia. J Med Assoc Thai, 61: 65-71.

Negi, RS 1968. Sickle cell trait in India A review of known distribution. Bull Anth Surv India, 17: 439449

Orkin SH, Kazazian HH Jr, Antonarakis SE, Oster H, Goff SC, Sexton P 1982. Abnormal RNA processing due to the exon mutation of the $\beta$-globin gene. Nature Lond, 300: 768-769.

Pagnier J, Mears JG, Dunda-Bellkhodja O, Schaefer-Rego KE, Beldjord C, Nagel RL, Labie D 1984. Evidence for the multicentric origin of the sickle cell hemoglobin gene in Africa. Proc Natl Acad Sci, USA, 81: 1771-1773.

Pembrey ME, Wood WG, Weatherall DJ, Perrine RP 1978. Fetal haemoglobin production and the sickle gene in the cases of Eastern Saudi Arabia. $\mathrm{Br} J$ Haematol, 40: 415-429.

Perrine RP, Pembrey ME, John P, Perrine S, Shoup F 1978. Natural history of sickle cell anemia in Saudi Arabs: A study of 270 subjects. Ann Intern Med, 88: 1 .

Persico MG, Viglietto G, Martino G, Dono R, D’Urso M, Toniolo D, Vulliamy T et al 1986a. Analysis of primary structure of human G6 PD deduced from the cDNA sequence pp503-516 In: Glucose-6Phosphate Dehydrogenase. A Yoshida, E Beutler (Eds.). Orlando, Fl: Academic Press.

Persico MG, Viglietto G, Martino G, Toniolo D, Paonessa G, Moscatelli C, Dono R, et al 1986b. Isolation of human Glucose-6-Phosphate Dehydrogenase cDNA clones: Primary structure of the protein and unusual 5' non-coding region Nucleic Acids Res, 14: 25112522,7822 .

Roy DN, Roychaudhuri SK 1967. Sickle-cell trait in the tribal populations of Madhya Pradesh and Orissa India. J Ind Med Ass, 49: 107.

Rucknagel DL, Neel, JV 1961. The hemoglobinopathies. In: Progress in Medical Genetics. Vol 1: p158. AG Steinberg, AG Bearn (Eds.). New York: Grune \& Stratton

Saha N 1988. Blood genetic markers in Sri Lankan populations - Reappraisal of the legend of Prince Vijaya. Am J Phys Anthrop, 76: 217-225.

Saha N 1990. Distribution of hemoglobin E in several Mongoloid populations of North-East India. Hum Biol, 62: 535-544.

Saha N, Mukhopadhyay B, Bhattacharyya SK, Gupta R, Basu A 1987. The distribution of transferrin, groupspecific component and phosphoglucomutase-1 subtypes among the Lepchas of Darjeeling, Eastern India. Jap J Hum Genet, 32: 311-318.

Saha N, Hong SH, Wong HA, Tay JSH 1990a.Red cell glucose-6-phosphate dehydrogenase phenotypes in several Mongoloid populations of eastern India: Existence of non-deficient fast variant in two 
Australian tribes. Ann Hum Biol, 17: 529-532.

Samuel APW, Saha N, Acquaye JK, Omer A, Ganeshaguru K 1986. Association of red cell glucose-6-phosphate dehydrogenase with haemoglobinopathies. Hum Hered, 36: 107-112.

Seth PK, Seth S 1971. Biogenetical studies of Nagas: Glucose-6-phosphate dehydrogenase deficiency in Angami Nagas. Hum Biol, 43: 557-561.

Siniscalco, M, Bernini, L, Latte B, Motulsky AG 1961. Favism and thalassaemia in Sardinia and their relationship to malaria. Nature Lond, 190: 11791180 .

Sonnet J, Michaux JL 1960. Glucose-6-phosphate dehydrogenase deficiency, haptoglobin groups, blood groups and sickle cell trait in the Bantus of West Belgian Congo. Nature Lond, 188: 504-505.

Steinberg AG, Undevia JV, Tepfenhart MA 1973. Gm and Inv studies of Parsi and Irani in India: Report of a new polymorphic haplotype Gm1,3,21. Am J Hum Genet, 25: 302-309.

Sukumaran PK, Sanghvi LD, Vyas GN 1956. Sickle cell trait in some tribes of Western India Curr Sci, 25: 290-291.

Takizawa T, Huang IY, Ikuta T, Yoshida A 1986. Human glucose-6-phosphate-dehydrogenase: Primary structure and cDNA cloning Proc Natl Acad Sci USA, 83: 4157-4161.

Tarlov AR, Brewer GJ, Carson PE, Alving AS 1962. Primaquine sensitivity: G6PD deficiency: An inborn error of metabolism of medical and biological significance. Archs Intern Med, 109: 209.

Toncheva D, Tzoneva M 1985. Prenatal selection and fetal development disturbances occuring in carriers of G6PD deficiency. Hum Genet, 69: 88.

Undevia JV 1973. Population Genetics of the Parsis. Miami: Field Research Projects Coconut Grove.

Undevia JV, Blake NM, Kirk RL, McDermid EM 1972. The distribution of some enzyme group systems among Parsis and Iranis of Bombay. Hum Hered, 22: $274-282$.

Undevia JV, Kirk RL, McDermid EM 1973. Serum protein systems among Parsis and Iranis of Bombay. Hum Hered, 23: 492-498.
Undevia JV, Saha N 1987. Distribution of transferrin and group specific component subtypes among Parsis of India. Hum Hered, 37: 205-210.

Vogel F, Motulsky AG 1997. Human Genetics, Problems and Approaches. 3rd Edition, Berlin, Heidelberg, New York, Tokyo: Springer Verlag.

Vyas GN, Bhatia HM, Sukumaran PM, Balakrishnan V, Sanghvi LD 1962. Study of blood groups, abnormal hemoglobins and other genetic characters in some tribes of Gujarat. Am J Phys Anthrop, 20: 255-265.

WHO 1966. Haemoglobinopathies and Allied Disorders. Geneva: WHO Technical Report Series No 338.

WHO 1967. Standardization of Procedures for the Study of Glucose-6-Phosphate Dehydrogenase. Technical Report Series No 366, Geneva: WHO.

Wainscoat JS, Higgs DR, Kanavakis E, Cao A, Geogrgiou D, Clegg JB, Weatherall DJ 1983. Association of two DNA polymorphisms in the $\alpha$-globin gene cluster Implications for genetic analysis. Am J Hum Genet, 35: 1086-1089.

Walter H 1998. Populationgenetik der Blutgruppensysteme des Menschen. Stuttgart: E. Schweizerbart'sche Verlagsbuchhandlung,

Wasi P 1983. Hemoglobinopathies in Southeast Asia. pp 179-203 In: Distribution and Evolution of Hemoglobin and Globin Loci. JE Bowman (Ed.). New York: Elsevier.

Wasi P, Na-Nakoran S, Suingdumrong A 1967. Studies on the distribution of haemoglobin $\mathrm{E}$, thalassaemia and G-6-PD deficiency in northeastern Thailand. Nature Lond, 214: 501-502.

Weatherall DJ, Clegg JB 1981. The Thalassaemia Syndromes. Oxford: Blackwell, 3rd Edition .

Wickremasinghe RL, Ponnuswamy NEL 1963. Blood groups and haemoglobin types of Ceylonese. Spolia Zeylon, 30: 149-154.

Wickremasinghe RL, Kin W, Mourant AE, Lehmann H 1963. The blood groups and haemoglobins of the Veddahs of Ceylon. JR Anthrop Inst, 93: 117-125.

Yoshida A, Takizawa T 1986. Molecular cloning of cDNA for G6PD pp 517-523 In: Glucose-6-Phosphate Dehydrogenase. A Yoshida, E Beutler (Eds.). Orlando, FL: Academic Press. 